\title{
Lithological description of subcropping Lower and Middle Triassic rocks from the Svalis Dome, Barents Sea
}

\author{
ATLE MØRK and GEIR ELVEBAKK
}

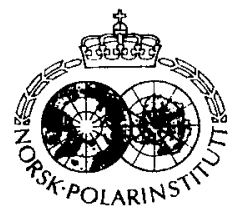

\begin{abstract}
Mørk, A. \& Elvebakk, G. 1999: Lithological description of subcropping Lower and Middle Triassic rocks from the Svalis Dome. Barents Se:i. Polar Research $/ 8(1), 83-104$.

Eleven shallow cores display $315 \mathrm{~m}$ of the $>700 \mathrm{~m}$ thick Lower and Middle Triassic succession of the Svalis Dome, a salt diapir in the central south-western Barents Sea. The Svalis Dome was uplifted in the late Mesozoic, and Triassic rocks suhcrop below Quaternary till around the Upper Palaeozoic core of the dome. Deposition of the Triassic stccession took place in deep shelf to basinal environments below storm wave base. The succession is dated by macrofossils and palynomorphs and can be assigned to four formations. The basal beds of the haly greenish grey Havert Formation (Griesbachian) occur above Permian bioclastic carbonate. The Klappmyss Formation (Smithian) in the lower part contains gravity flow sands deposited as submatrine fins ponsibly triggcred by tectonic movements along the adjacent fault zones overlain by silty elaystones. An wrganic-rich dark shale unit is here formally defined as the Steinkobbe Formation, and was deposited in a large bight by restricted water circulation. The Snadd Formation. on top, represents a marine shelf unit deposited in front of an emerging land area in the north-east. A minimum of six higher order transgressive-regressive sequences are recognized at the Svalis Dome and these are correlated with other Arctic areas.
\end{abstract}

A. Mork and G. Elvehakk, IKU/SINTEF Petroleum Re'search, N-746.5 Trontheim, Norwa; G. Elwebakk (present address), Saga Petroleum 4.SA. P.O. Box 1134, N-9401 Harstad. Norway.

\section{Introduction}

The Svalis Dome is a diapiric structure in the southern part of the Barents Sea $\left(733^{\prime} 15^{\prime} \mathrm{N}\right.$. 23 20'E: Fig. 1; Gabrielsen et al. 1990) where Upper Palaeozoic and Mesozoic rocks outcrop at the sea bottom, or subcrop below Quaternary cover. The structure was discovered in 1974 during seismic studies (Sundvor 1974) and described by Kristoffersen \& Elverhøi (1978), who also described dredged rocks from the central parts of the structure. The structure has been intensely drilled by IKU Petroleum Research since 1984 as a part of the IKU-Barents Sea Mapping Program (Bugge \& Fanavoll 1995). The shallow drilling technique used in this programme has been described by Rise \& Sxttem (1994).

The central part of the Svalis Dome consists of Upper Palaeozoic carbonates, evaporites and alternating silicified shales and carbonates (Nilsson et al. 1996). These resistant rocks today form a positive sea bottom relief as they are surrounded by more easily eroded softer Mesozoic siliciclastics. The Svalis Dome is intersected by several fault zones giving the structure a triangular shape (Fig. 1). Large-scale tectonism with predominantly north-south to NE-SW orientated normal faults is recognized along the western boundary faults of the Loppa High. The high itself was uplifted and tilted towards the east from the early Permian onwards. The crestal parts of the high were subaerially exposed from the Late Permian. Lower and Middle Triassic sequences progressively onlap the eastern flank of the high until the Early Ladinian when the high subsided and was transgressed (Wood et al. 1989; Johansen et al. 1993).

Triassic rocks are widely distributed in the Barents Sea as interpreted from seismic records (Rønnevik 1981; Rønnevik et al. 1982; Faleide et al. 1984: Rasmussen et al. 1993; Van Veen et al. 1993). Equivalent rocks are also penetrated by exploration wells and IKU shallow cores in the south-western part of the Barents Sea (Jacobsen \& Van Veen 1984; Worsley et al. 1988; Van Veen et al. 1993; Rasmussen et al. 1993; Bugge. Mangerud et al. 1995) and in the Russian part of the Barents Sea (Gramberg 1988). The general development of the Triassic succession in the Barents Sea and surrounding land areas was reviewed by Mørk, Vigran, Korchinskaya et al. (1993), while an overview of this succession's potential as a source for hydrocarbons was presented by Leith et al. (1993). 

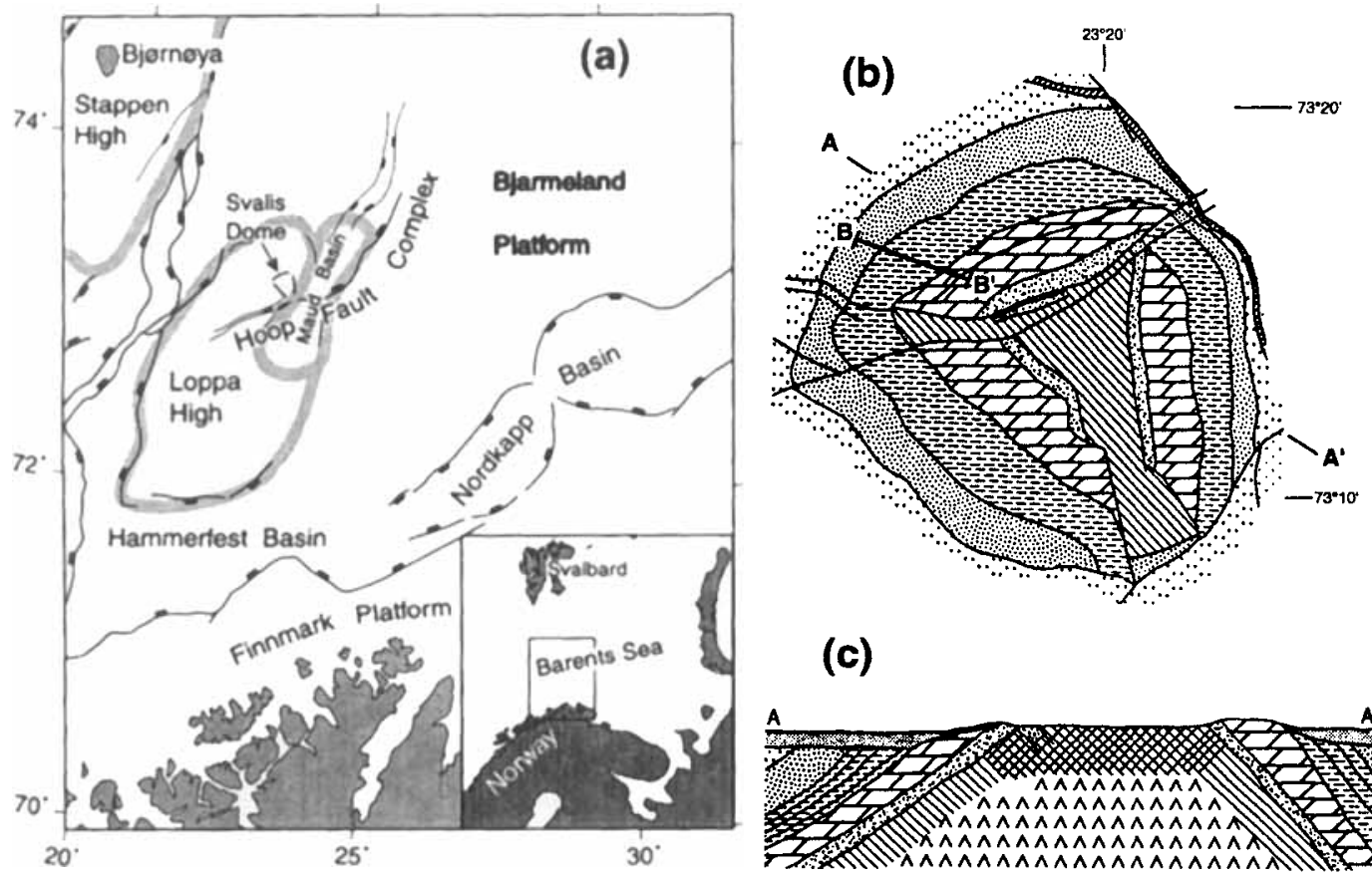

(c)
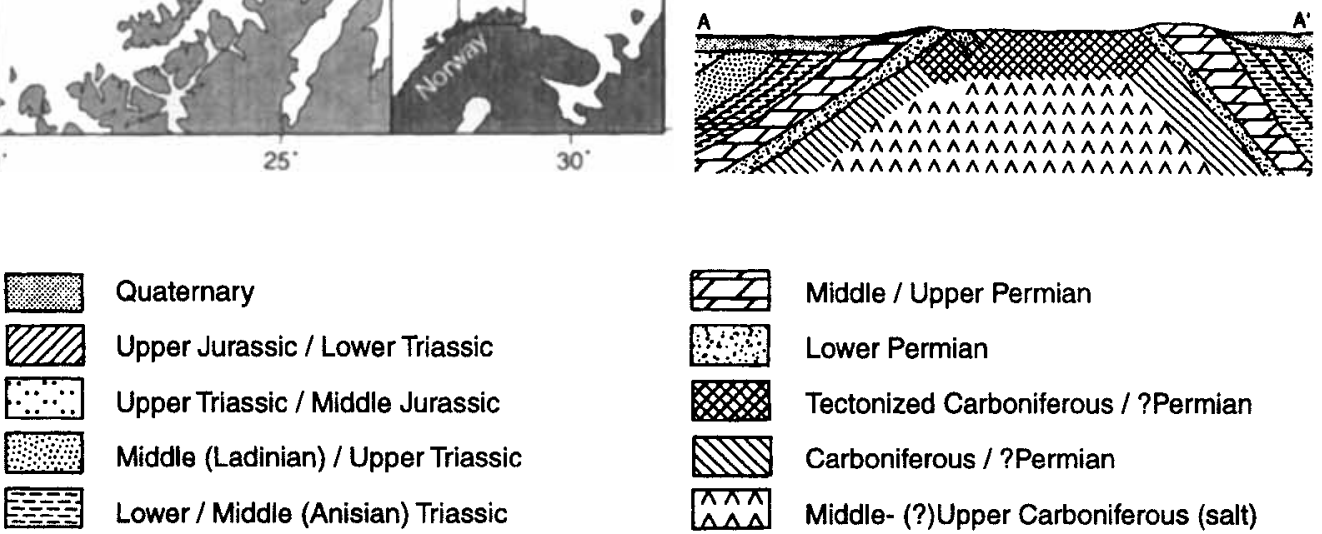

Quaternary

Upper Jurassic / Lower Triassic

Upper Triassic / Middle Jurassic

Middle (Ladinian) / Upper Triassic

Lower / Middle (Anisian) Triassic
E3 Middle / Upper Permian

Lower Permian

Tectonized Carboniferous / ?Permian

Carboniferous / ?Permian

Middle- (?)Upper Carboniferous (salt)

Fig. I. Geological setting of the Svalis Dome. (a) Location map; major structural elements and fault lines are indicated. (b) Svalis Dome map. (c) Schematic cross section of the Svalis Dome.

The Triassic succession at the Svalis Dome has been penetrated by eleven shallow cores with a diameter of $5.4 \mathrm{~cm}$ and lengths from 3 to $42 \mathrm{~m}$, giving a total of $315 \mathrm{~m}$ of core from an approximately $700 \mathrm{~m}$ thick succession (Figs. 2, 3, 4). All the cores through the Triassic rocks were drilled on the north-western flank of the dome. Nine of the eleven cores were drilled along one seismic line (Fig. 2); the remaining two were close to this line and their relative positions are indicated on Fig. 2.

Based on the cores from the Svalis Dome, the lithostratigraphy of this part of the Barents Sea is emended, and the different units are correlated with the surrounding areas (Fig. 5). The cores are assigned to the Havert, Klappmyss and Snadd formations as defined by Worsley et al. (1988) in the Hammerfest Basin; however, the Spathian and Anisian succession is herein defined as the Steinkobbe Formation. In this paper emphasis will be placed on the sedimentology and geological development of the drilled part of the Triassic succession. The biostratigraphic framework, based on ammonoids and palynology, the sequence stratigraphy and correlations to other areas are presented by Vigran et al. (1998). For descriptive purposes the cores are subdivided into units which are assigned an informal alphabetic notation. The cores are also assigned to different lithofacies types mainly reflecting the energy levels during deposition on different parts of the palaeoshelf (Figs. 3, 4). 


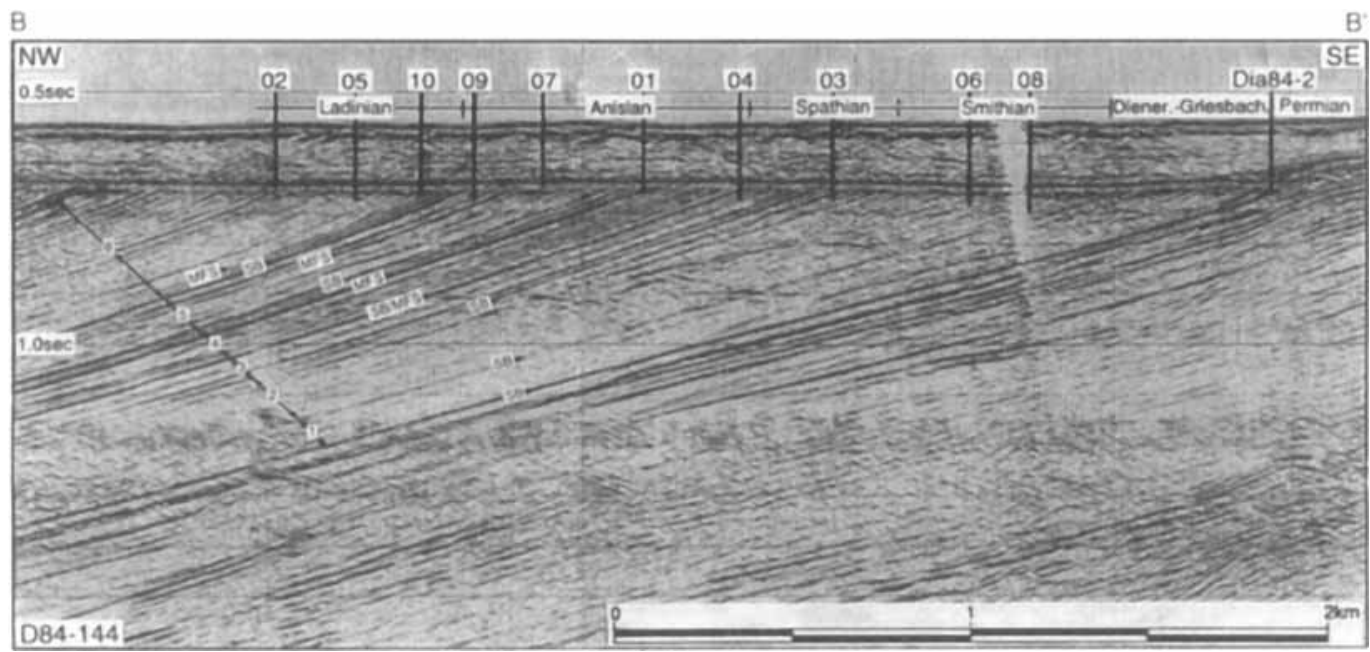

Fig. 2. Seismic section with core localities.

\section{Lithological description}

\section{Permian limestone and Havert Formation; core Dia84-2}

The core penetrated the Permian-Triassic boundary (at $98.57 \mathrm{~m}$; Figs. 6, 7), which corresponds to a pronounced seismic reflector that can be correlated around most of the Svalis Dome (Bugge \& Fanavoll 1995).

The limestone $(0.26 \mathrm{~m}$ thick; see Nilsson et al. 1996) consists of a lower, slightly siliceous packstone bed overlain by a fossiliferous grainstone. The limestone contains fossil debris of bryozoans, brachiopods and echinoderms and minor amounts of siliciclastic sand grains. This limestone resembles beds assigned to the Miseryfjellet Formation of Bjørnøya of late Permian age (Worsley \& Edwards 1976).

Havert Formation, unit A.-Twenty-five metres of greenish grey laminated silty shale overlie the limestone (Figs. 6, 7). The top boundary of the limestone is sharp; crinoidal debris and small dark grey/black phosphorite fragments occurs in the lowermost centimetre of the shale, indicating reworking/condensation of the underlying bed.

Thin $(1-10 \mathrm{~cm})$ siltstone beds and lenses occur repeatedly. The silt grains consist of quartz. feldspar and mica. Calcite is the most abundant cementing mineral, but a few crystals of dolomite also occur. Minor concretions or lenses of calcite also occur throughout the succession. The carbonate beds and/or nodules are mainly composed of recrystallized calcite, with a microspar texture. Partly dissolved bivalve fragments are present and pyrite is abundant. Bivalve fragments are found throughout the core, while a few compacted and poorly preserved ammonoids are also present (Vigran et al. 1998). Bioturbation is sparse. The total organic carbon (TOC) content is close to one percent $(0.3-1.3 \%)$ and consistent throughout the core (Fig. 6).

Klappmyss Formation; cores 7323/07-U-08, $U$ $06, U-03$

The boundary between the Havert and Klappmyss formations was not drilled, but a reflector approximately $37 \mathrm{~m}$ below core $7323 / 07-\mathrm{U}-08$ is a possible candidate for this contact (Fig. 2; Bugge \& Fanavoll 1995). Three cores represent the Klappmyss Formation (Figs. 8, 9), and the uppermost core shows the transition to the overlying Steinkobbe Formation (Figs. 3, 8). The organic content is low in the sandstones $(<0.5 \%)$ and has a mean of $0.7 \%$ in the upper unit.

Unit B.-The core was drilled through the lower part of a transparent seismic unit, and a faint seismic reflector is correlated to the lithological change at $119.7 \mathrm{~m}$ in the core. The unit (below 


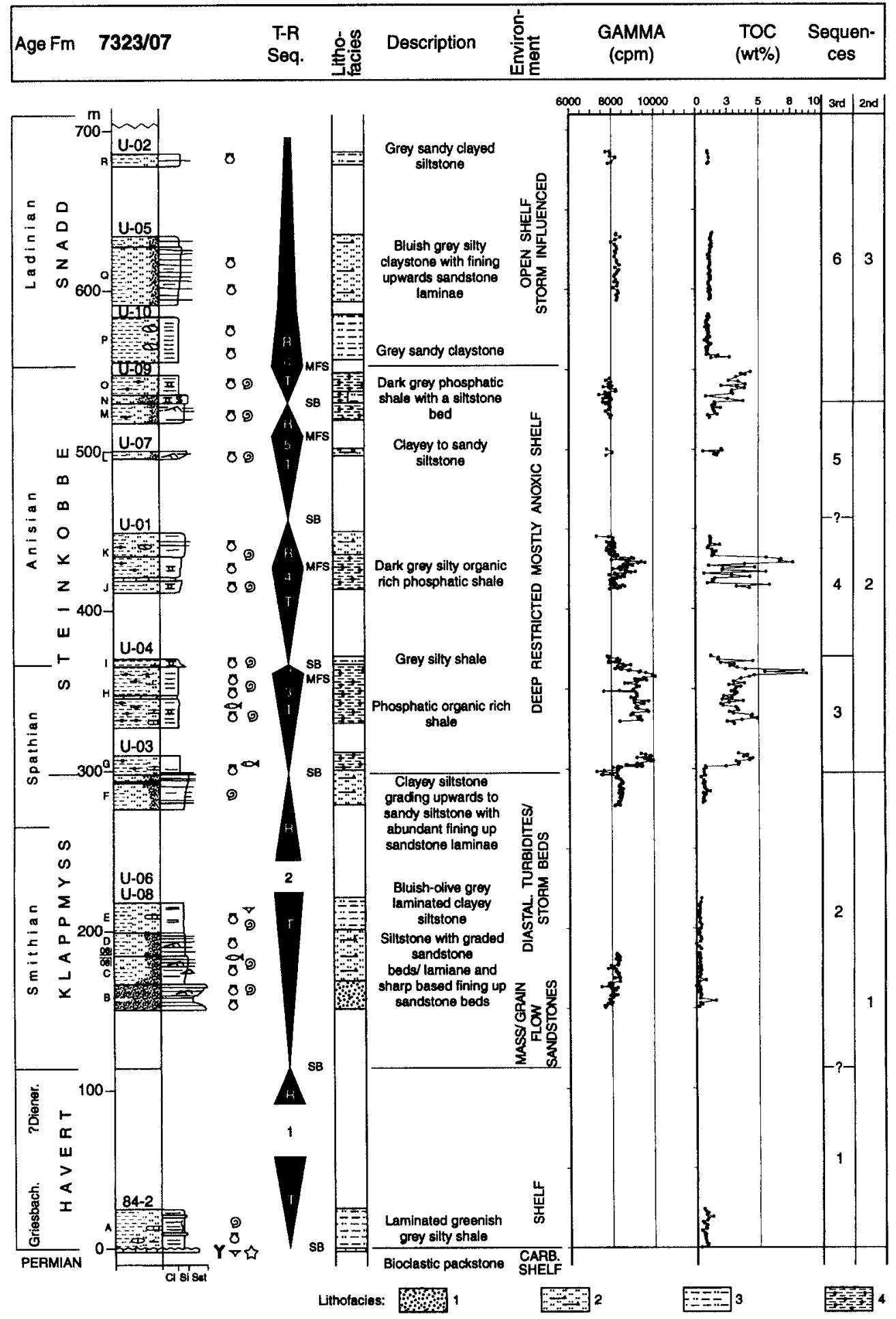

Fig. 3. Summary section for Triassic Svalis Dome cores. The lithofacies types represent energy level and depositional processes. see text (legend with Fig. 6). 


\begin{tabular}{|c|c|c|c|c|c|c|c|c|c|}
\hline $\begin{array}{c}\text { Core } \\
\text { no. in } \\
\text { block } \\
7323 / 07\end{array}$ & \begin{tabular}{|c} 
Bedrock \\
coring \\
$\mathbf{m}$ \\
$\%$
\end{tabular} & $\begin{array}{c}\text { Formation } \\
\mathrm{m}\end{array}$ & Unit & $\begin{array}{l}\text { Litho- } \\
\text { facies }\end{array}$ & Lithology & Age & $\begin{array}{c}\text { Sequence } \\
\text { interp. }\end{array}$ & Position & $\begin{array}{c}\text { Seismic } \\
\text { line } \\
\text { Shot } \\
\text { Point }\end{array}$ \\
\hline $\mathrm{U}-02$ & 8.4 & \multirow{3}{*}{$\begin{array}{l}\text { Snadd } \\
100+ \\
(135) \\
\text { or } \\
(270)\end{array}$} & $\mathbf{R}$ & 3 & $\begin{array}{l}\text { Laminated silt- and } \\
\text { claystones }\end{array}$ & \multirow{3}{*}{$\begin{array}{c}\text { Early } \\
\text { Ladinian }\end{array}$} & \multirow{3}{*}{6} & $\begin{array}{l}73^{\circ} 17^{\prime} 00.3^{\prime \prime N} \\
23^{\circ} 00^{\prime} 48.2^{n E} \mathrm{E}\end{array}$ & $\begin{array}{c}\text { D84-144 } \\
1986\end{array}$ \\
\hline U-05 & $\begin{array}{r}43.0 \\
100.0\end{array}$ & & $Q$ & 2 & $\begin{array}{c}\text { Laminated siltstones } \\
\text { with graded sandstone } \\
\text { laminae }\end{array}$ & & & $\begin{array}{l}73^{\circ} 16^{\prime} 56.7^{\mathrm{N} N} \\
23^{\circ} 01^{\prime} 09.2^{\prime \prime} \mathrm{E}\end{array}$ & $\begin{array}{c}\text { D84-144 } \\
1968\end{array}$ \\
\hline U-10 & $\begin{array}{l}27.2 \\
95.6\end{array}$ & & $\mathbf{P}$ & 3 & $\begin{array}{l}\text { Laminated silt- and } \\
\text { claystones }\end{array}$ & & & $\begin{array}{l}73^{\circ} 16^{\prime} 51.5^{\prime \prime N} \\
23^{\circ} 01^{\prime} 25.8^{\prime \prime E}\end{array}$ & $\begin{array}{c}\text { D84-144 } \\
1953\end{array}$ \\
\hline \multirow{3}{*}{ U-09 } & \multirow[t]{2}{*}{29.2} & \multirow{9}{*}{$\begin{array}{l}\text { Stein- } \\
\text { kobbe } \\
255\end{array}$} & 0 & 4 & Phosph. org. rich shale & \multirow{4}{*}{ Late Anisian } & \multirow{2}{*}{6} & \multirow{3}{*}{$\begin{array}{l}73^{\circ} 16^{\circ} 51.0^{\prime \prime N} \\
23^{\circ} 01^{\prime} 43.1^{n E}\end{array}$} & \multirow[t]{2}{*}{ D84-144 } \\
\hline & & & $\mathbf{N}$ & 3 or 4 & Lamin. silt- \& clayst. & & & & \\
\hline & 99.6 & & $M$ & 4 & Phosph. org rich shale & & \multirow{2}{*}{$\begin{array}{c}\text { MFS } \\
5\end{array}$} & & 1940.5 \\
\hline U-07 & 97.4 & & L & 2 & $\begin{array}{c}\text { Laminated siltstones } \\
\text { with graded sandstone } \\
\text { laminae }\end{array}$ & & & $\begin{array}{l}73^{\circ} 16^{\prime} 47.6^{\prime \prime N} \\
23^{\circ} 02^{\prime} 03.5^{\prime \prime E}\end{array}$ & $\begin{array}{l}\text { D84-144 } \\
1924.5\end{array}$ \\
\hline \multirow{2}{*}{ U-01 } & 33.2 & & K & 2 & $\begin{array}{l}\text { Lam. siltst. with } \\
\text { graded sandst. lamin }\end{array}$ & \multirow{2}{*}{$\begin{array}{l}\text { Middle } \\
\text { Anisian }\end{array}$} & \multirow{2}{*}{$\begin{array}{c}4 \\
\text { MFS }\end{array}$} & & D84-144 \\
\hline & $\frac{100.0}{125}$ & & $J$ & 4 & Phosph. org. rich shale & & & $23^{\circ} 02^{\prime} 32.2^{\prime \prime} \mathrm{E}$ & 1900.5 \\
\hline \multirow{2}{*}{ U-04 } & \multirow[t]{2}{*}{43.5} & & I & 3 & $\begin{array}{l}\text { Laminated silt- and } \\
\text { claystones }\end{array}$ & Early Anisian & 4 & \multirow[t]{2}{*}{$73^{\circ} 16^{\prime} 37.7^{\prime \prime N}$} & L84-144 \\
\hline & & & H & 4 & Phosph. org. rich shale & Late Spathian & \multirow{2}{*}{$\begin{array}{c}\text { SB } \\
\text { MFS } \\
3\end{array}$} & & 1876.5 \\
\hline \multirow{2}{*}{ U-03 } & \multirow[t]{2}{*}{33.2} & & $G$ & 4 & Phosph. org. rich shale & ?Spathian & & $73^{\circ} 16^{\prime} 33.7^{\prime \prime} \mathrm{N}$ & D84-144 \\
\hline & & \multirow{5}{*}{$\begin{array}{l}\text { Klapp- } \\
\text { myss }\end{array}$} & $F$ & 2 & $\begin{array}{l}\text { Lam. siltst. with } \\
\text { graded sandst. lamin }\end{array}$ & $\begin{array}{c}\text { ?Spathian / } \\
\text { Late Smithian }\end{array}$ & SB & $23^{\circ} 03^{\prime} 26.4^{\prime \prime} \mathrm{E}$ & 1856 \\
\hline \multirow{2}{*}{ U-06 } & \multirow[t]{2}{*}{35.0} & & $E$ & 3 & $\begin{array}{l}\text { Laminated silt- and } \\
\text { claystones }\end{array}$ & \multirow{4}{*}{$\begin{array}{c}\text { Late } \\
\text { Smithian }\end{array}$} & \multirow{4}{*}{2} & \multirow{2}{*}{$\begin{array}{l}73^{\circ} 16^{\prime} 26.6^{\prime \prime N} \\
23^{\circ} 04^{\prime} 00.5^{\prime \prime E}\end{array}$} & \multirow[t]{2}{*}{ D84-144 } \\
\hline & & & D & 2 & $\begin{array}{c}\text { Lam. siltst. with } \\
\text { graded sandst. lamin }\end{array}$ & & & & \\
\hline U-08 & 34.8 & & C & 2 & $\begin{array}{l}\text { Lam. siltst. with } \\
\text { graded sandst. lamin }\end{array}$ & & & $73^{\circ} 16^{\prime} 22.8^{\prime \prime} \mathrm{N}$ & D84-144 \\
\hline & 100.0 & & B & 1 & Sandstone & & & $23^{\circ} 04^{\prime} 24.4^{\prime \prime} \mathrm{E}$ & 1805.5 \\
\hline Dia84-2 & 25.0 & $\begin{array}{c}\text { Havert } \\
115\end{array}$ & A & 3 & $\begin{array}{l}\text { Laminated silt- and } \\
\text { claystones }\end{array}$ & Griesbachian & 1 & $73^{\circ} 16^{\prime} 41.3^{\prime \prime} \mathrm{N}$ & D84-145 \\
\hline & 93.7 & & & & Bioclastic limestone & Late Permian & SB & $23^{\circ} 09^{\prime} 28.6^{\prime \prime} \mathrm{E}$ & 1708.4 \\
\hline
\end{tabular}

All cores are drilled between 417 and $426 \mathrm{~m}$ water depth.

Quaternary overburden is between 74 and $104 \mathrm{~m}$ thick.

Fig. 4. Core summary and technical data. 


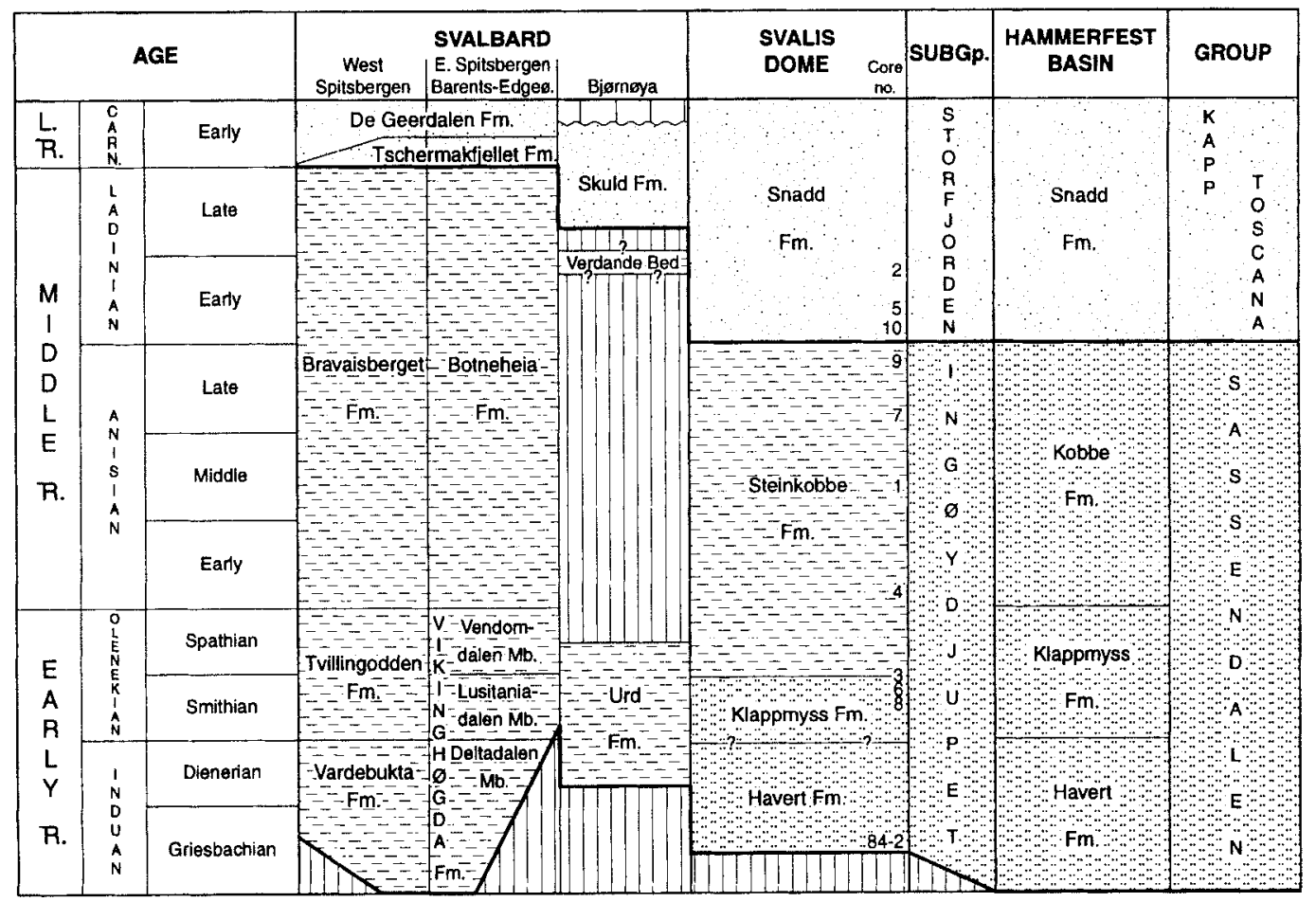

Fig. 5. Stratigraphical scheme.

$119.7 \mathrm{~m}$ ) forms a fining upwards succession of sandstone with thin interbeds of silt and silty claystones (Fig. 8). The fining upwards pattern results from an upward decrease in bed thickness, upward change from fine-grained to very finegrained sandstone and upward increase in the amount of mudstone. The lower $3 \mathrm{~m}$ consist of fine-grained massive sandstone beds each up to $65 \mathrm{~cm}$ thick.

The base of each bed is normally sharp and erosional with sole marks. Most of the beds show a fining upward grain size trend illustrated in Fig. 8. The thicker beds typically show an upward transition from massive through parallel to ripple lamination. Occasionally climbing ripples or convolute bedding occur. The upper part grades into horizontally laminated very fine-grained sand and silt and at the top into slightly bioturbated mud. Mud clasts may occur close to the base of the bed while wood fragments and plant debris are concentrated in the upper laminated silty part. Bivalves occur in the shale between the sandstone beds. Bioturbation is sparse in these sandstones.
Unit C.- - This has a sharp base and is dominated by siltstone with some graded sandstone beds. The sandstone beds often have horizontal laminated lower parts overlain by low angle ripple lamination. Gradation into overlying horizontal laminated siltstone often occurs. Several of the beds show convolute bedding. Flaser bedding may be present in the siltstones. Some grey coloured calcite concretions are up to $3 \mathrm{~cm}$ in diameter. Bioturbation is very sparse in this unit, while bivalve fragments and fish scales are abundant. A few ammonoids and inarticulate brachiopods are present while wood and leaf fragments and megaspores occur more sporadically. Small faults with a vertical displacement of up to $1 \mathrm{~cm}$ are present. Laminae close to such faults have been bent indicating that this deformation occurred early. At $111.5 \mathrm{~m}$ and $110.5 \mathrm{~m}$ angular siltstone fragments occur close to a small fault showing that the faulting took place contemporaneously with sedimentation. This activity may be related to movements along the Hoop Fault Complex or parallel minor faults as indicated by Bugge \& Fanavoll (1995). 
Fig. 6. The Havert Formation and legend for sections.

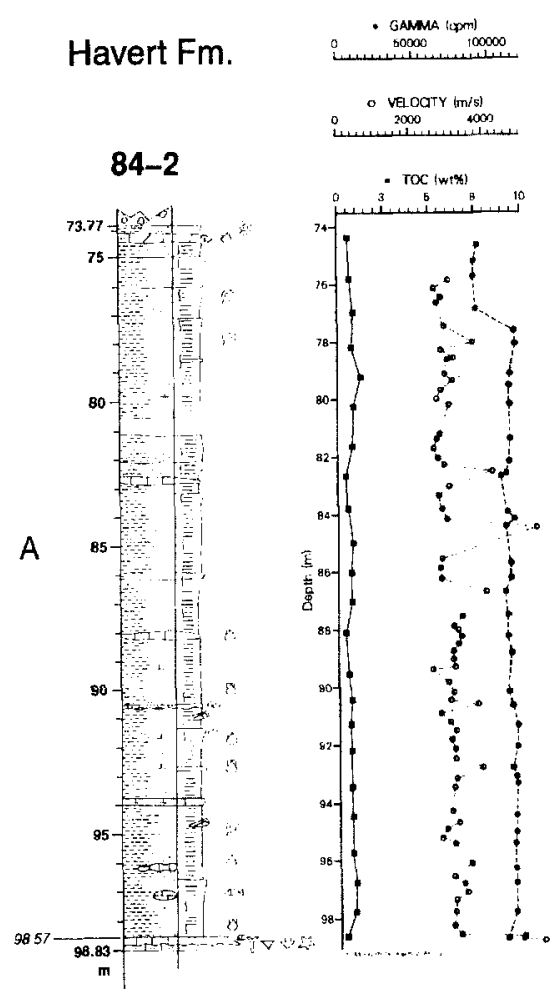

\section{Legend}

Q Quatemary morain

Sandstone

Slltstons

E- Claystone/mudstone

Organic rich mudstone

Limestone

Dolomite

Sidertite

Pyrite

G Glauconite

$\bigcirc$ Nodule

Phosphate nodule

Fi Phosphate nodule

- Calctte cement

2. Siderite cement

5 Lanticular lamination

Fining up lamina

Ripple lamination

Lanticular and ripple lamination

Planar lamination

Cross bedding

Hummocky bedding

[-1) Mud flakes

Mud drapes

2 Soft sediment deformation

च Loading

Erosional surface

$\rightarrow$ Small fault

$\hat{0}$ Unidentified fossil traggnent

(2) Ammonoids

8 Bivalves

$\approx$ Coquina

, Cephalopod hooks

Y Bryozoans

$\nabla$ Brachlopods

$\leftrightarrow$ Productld brachiopods

it Echinoderms

- Gastropod

Fish remains

$0 / \Delta$ Wood/Plant fragments

$\Rightarrow \quad$ Verrebrate bones

1 Mixosaunus

S-IIff Increasing bioturbation

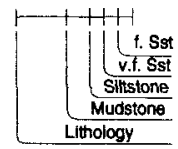

Unit D.-This consists of bluish to olive-grey laminated silty claystone with abundant sand laminae and beds, and occasional limestone nodules. In this unit a coarsening upward trend is displayed as the frequency of sandstone beds increases upward. Thicker sandstone beds, up to $6 \mathrm{~cm}$, are common up to $119.25 \mathrm{~m}$, and such beds show multiple current rippling; at $120.8 \mathrm{~m}$ the current ripples have opposing directed dips. Load casts and convolute lamination occurs sporadically. Many of the sandstone laminae have sharp or occasionally erosional bases and they show an upward gradational transition into the overlying siltstone. These sandstones are either horizontally laminated, graded or show low angle ripple lamination. The interbedded siltstone, often calcareous, may show bioturbation and contain bivalve shells. Such graded couplets vary in thickness between 1 and $30 \mathrm{~mm}$. The intensity of bioturbation is very low. Bivalve fragments are abundant throughout the unit, with complete specimens in the upper part. Ammonoids, belem- 


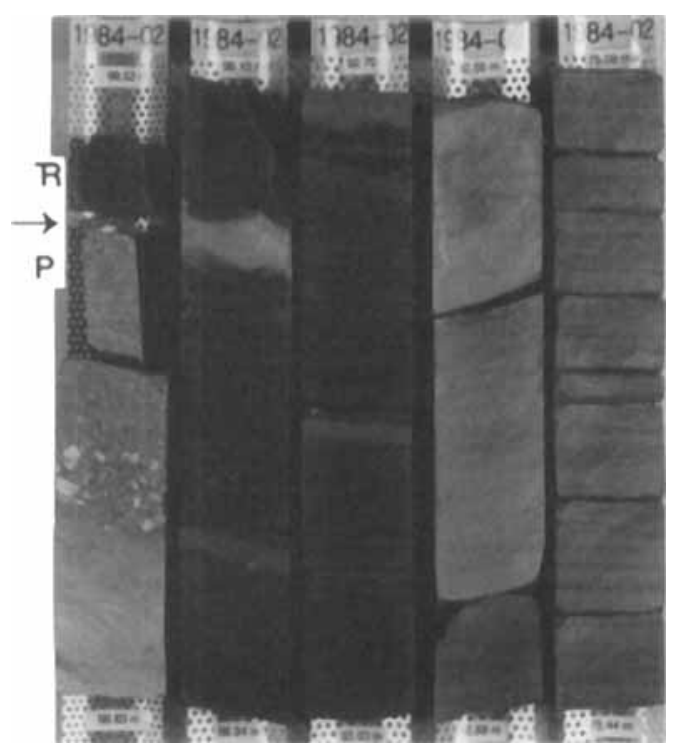

Fig. 7. Core photos from the Havert Formation. Each core is $5 \mathrm{~cm}$ wide.

nites, cephalopod hooks, fish scales and wood fragments are also present.

Unit E.-This also consists of bluish to olive-grey laminated clayey siltstone with minor sandstone laminae and thin beds. Sandstones are most common in the lower part of the unit. These sandstones resemble those of the underlying unit, while the upper part of unit $E$ is characterized by alternating siltstones and clayey siltstone beds, often with sharp contacts. Thin graded siltstone to very fine-grained sandstone beds, occasionally showing convolute lamination, are common in the upper part of the unit. Calcite concretions occur throughout this core and the larger of these $(<7 \mathrm{~cm}$ in diameter) are ellipsoid with long axes parallel to the bedding. The smaller concretions $(<1 \mathrm{~cm}$ in diameter) are more spherical in shape. Bivalves occur throughout the unit, but are most common in the lower part of the unit, while lingulid brachiopods are present between 105 and $101 \mathrm{~m}$. Fish remains and leaf fragments are also observed.

Unit F.-This has a $1.5 \mathrm{~m}$ thick clayey siltstone at its base, while the remainder of the unit consists of laminated clayey and sandy siltstone. Abundant laminae grading from sandstone to siltstone occur throughout the unit, but become more abundant upwards, giving the unit an overall coarsening upward trend. Few of these laminae show convolute bedding. In the upper part a few rippled laminae also occur. Towards the top of the unit thin sandstone beds show rippled tops. Micaceous (dominantly muscovite) beds are abundant, glauconite is present, and the sandstones are mostly cemented by calcite. Two laminated sandy dolomite beds/nodules with septarian veins occur at 112 and $110 \mathrm{~m}$. Sparse bioturbation is observed in the lower part of the unit. Only a few fragments of wood, ammonoids, fish remains and cephalopod hooks as well as sparse shell debris are observed.

Steinkobbe Formation; cores 7323/07-U3, U-04, $U-01, U-07, U-09$

The Steinkobbe Formation as defined in this paper (see Appendix) is dominated by dark, phosphatic, organic-rich "paper" shales although siltstones and mudstones without phosphate are also present (Figs. 10, 11). The lower boundary is defined where greyish siltstone is abruptly overlain by black shale. This boundary corresponds to a marked increase in both gamma radiation and TOC values (Fig. 10). TOC values are generally high for the Steinkobbe Formation (1.5-9\%). The gamma ray values show similar trends as the organic content, being higher in the black shales than in the clayey siltstones. Throughout the formation the sonic velocity values are close to $2000 \mathrm{~m} / \mathrm{s}$.

Unit G.-This sharply overlies the siltstones of unit F (Figs. 2, 10). The basal increase in gamma radiation correlates with the increase in the content of organic carbon to $4 \%$, a value that is consistent upwards through the unit. The basal $1.5 \mathrm{~m}$ is silty, passing up into dark grey, welllaminated, slightly silty shale with phosphorite and pyrite nodules. A $7 \mathrm{~cm}$ thick conglomerate of phosphorite pebbles is present at $105.4 \mathrm{~m}$. There are abundant macrofossils, dominated by fish remains (teeth, scales and bones), small bivalves and cephalopod hooks. Faecal pellets are abundant in the lowermost part of the unit.

Unit H.-This consists of well-laminated dark grey, soft, silty shale rich in fossil fragments. A few millimetre-thick siltstone laminae are also present. Calcite cement occurs throughout the unit. In calcite cemented beds the bivalve shells 


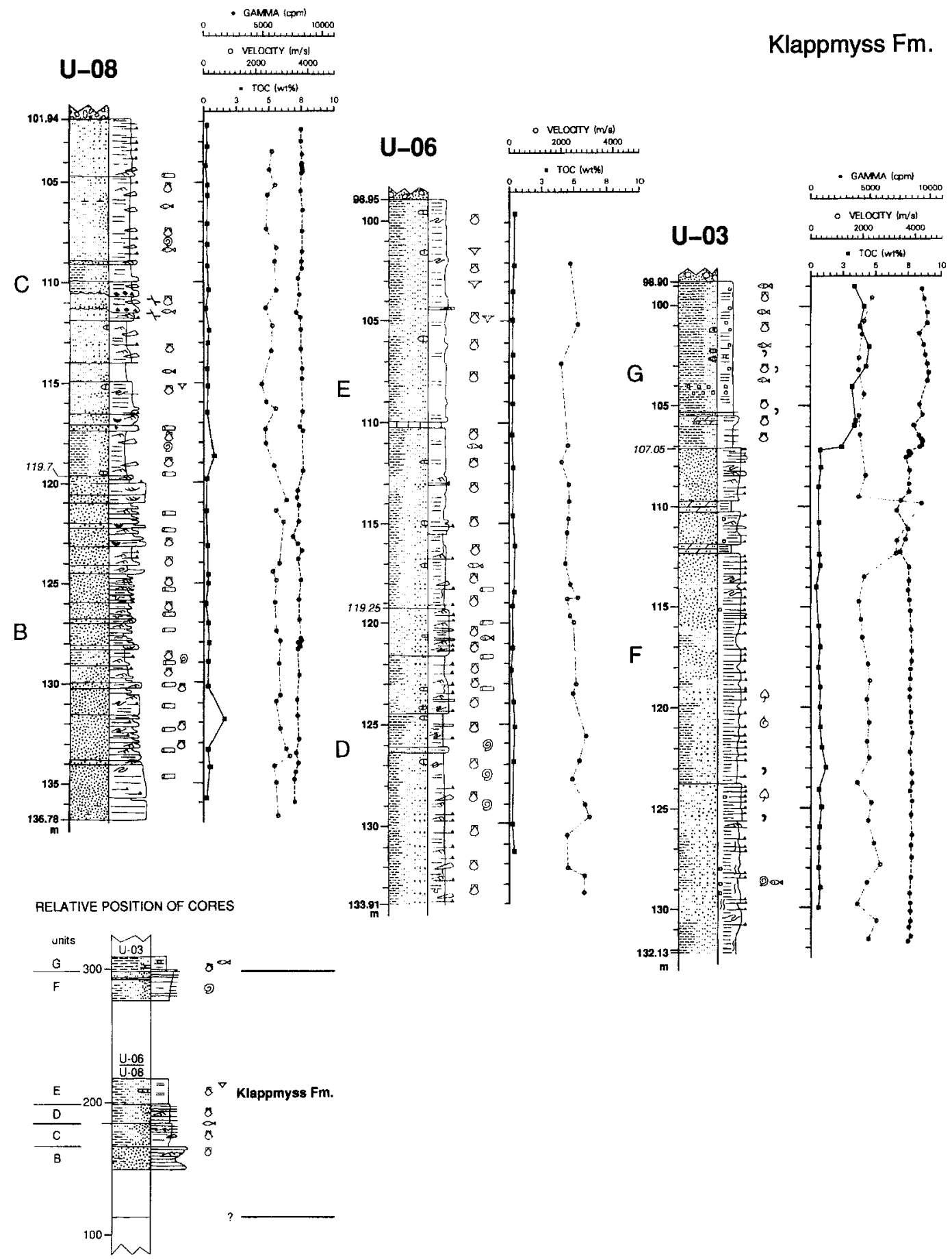

Fig. 8. The Klappmyss Formation (legend with Fig. 6). 


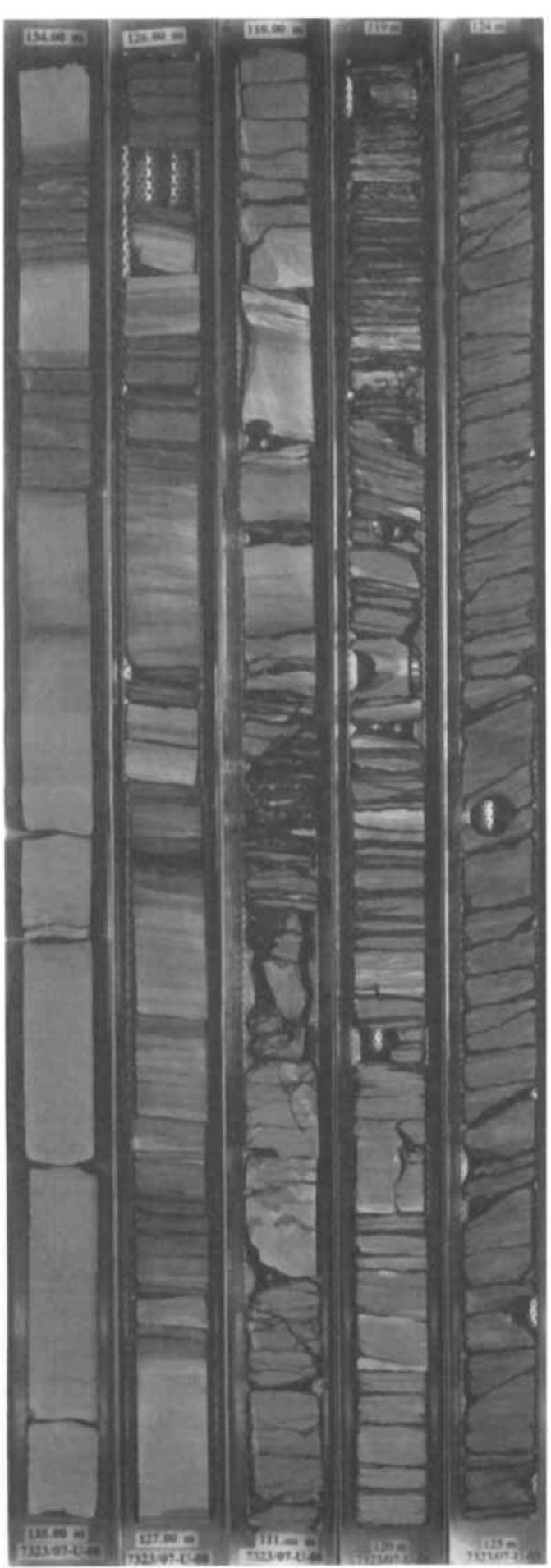

Fig. 9. Core phoros from the Klappmyss Formation. Euch core is $5 \mathrm{~cm}$ wide. are well-preserved whereas elsewhere they are preserved mostly as calcite-filled moulds. Small concretions are common, mostly of calcite, but in the lower part also of phosphorite. Nodules/beds of dolomite and limestone are up to $30 \mathrm{~cm}$ thick and some contain silt grains. Laminae in the embedding shales often show compactional bending around the concretions indicating that these formed at an early precompactional stage.

There are abundant macrofossils (Fig. 10), dominated by fish remains (teeth. scales and bones), small bivalves, ammonoids and cephalopod hooks. Bivalve fragments are common in the concretions. Belemnites and lingulid brachiopods occur as single specimens or a few specimens, together with vertebrate bone fragments and a jaw of the swimming reptile Mixosaurus. (The Mixosaurus fragment is similar to specimens from Mixosaurus cornalianus of Middle Triassic sediment from Switzerland, R. Wild, Stuttgart, pers. comm.) Mixosaurus nordenskioldi is also reported from the Upper Saurie Niveau (upper Lower Triassic) of central Spitsbergen (Hulke 1873).

Unit I.-This consists of medium dark grey silty shale. Its base is marked by a $70 \mathrm{~cm}$ thick greyish green siltstone bed with a sharp basal contact. The bed contains thin calcareous laminae and small black and globular phosphorite nodules/pebbles. Fragments of predominately bivalves and ammonoids are common. The basal silty bed is overlain by well-laminated black shales with yellowish brown phosphorite nodules/beds with abundant fossil fragments as in the underlying unit.

Unit $J$. - This consists of three stacked coarsening upward subunits. Each of these subunits is caused by a lower dark grey, unbioturbated and phosphoritic silty shale overlain by bioturbated grey silty shales with thin, very fine-grained sandstone beds. There is a thin limestone bed with abundant bivalve fragments at the top of the lower coarsening upward subunit. Bivalves and fish remains occur throughout the unit, while ammonoids dominate in the lowermost part.

Unit K.-This consists of medium grey and bioturbated clayey siltstone. This unit has a sharp base towards the underlying black shales. The lower $8 \mathrm{~m}$ are dominated by siltstone. while the middle part of the unit contains abundant thin siderite cemented beds and graded sandstone 


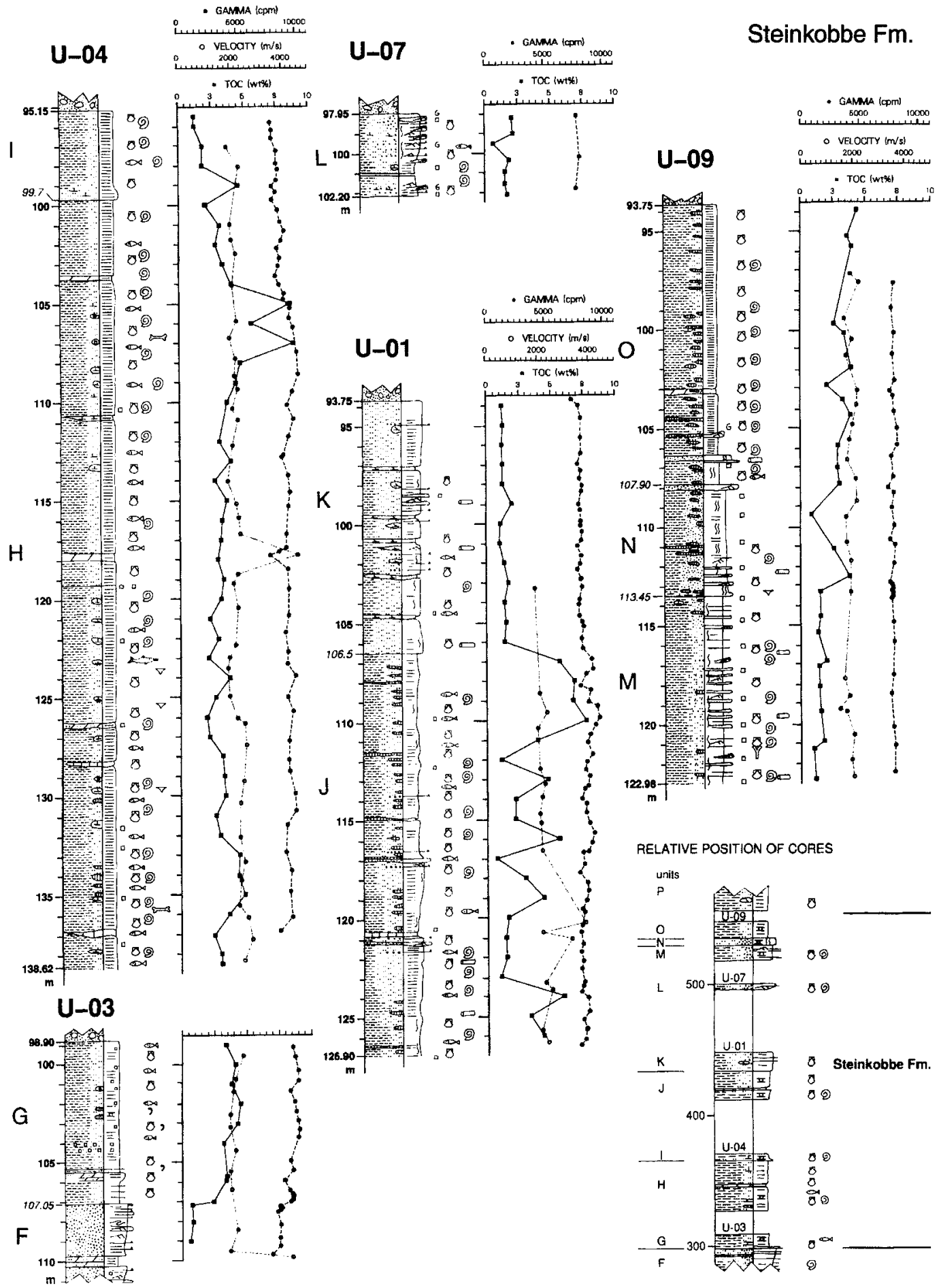

Fig. 10. The Steinkobbe Formation (legend with Fig. 6). 


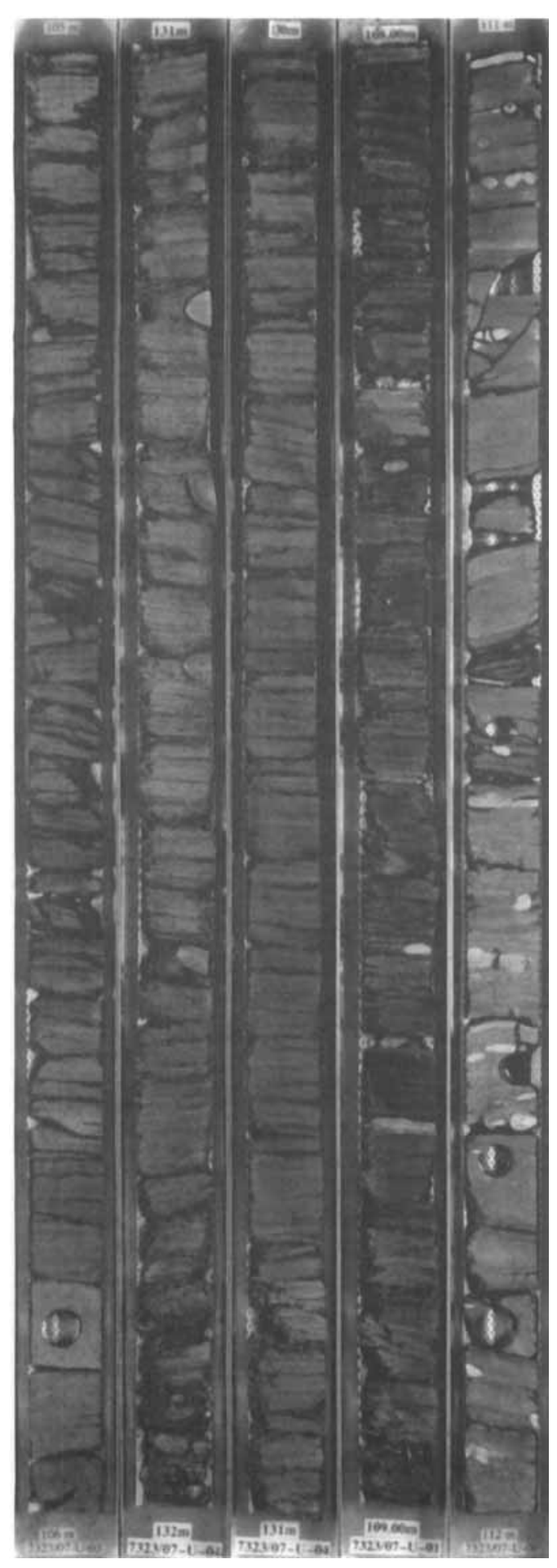

Fig. 1I. Core photos from the Steinkobbe Formation. Each core is $5 \mathrm{~cm}$ wide. laminae, some of which show climbing ripple drift lamination. Scarce fragments of bivalves and ammonoids are present.

Unit L.-This consists of bioturbated clayey to sandy siltstone with abundant graded sandstone laminae and thin beds. Between 101.7 and $100.45 \mathrm{~m}$ the core consists of medium dark grey silty claystone. Abundant sandstone laminae that occur below and above the silty claystone interval show sharp and often erosional bases and planar lamination in the lower parts. Such beds often grade upwards into ripple drift lamination. Horizontal burrows are common in the upper part of the unit. Pyrite is abundant and a few small phosphorite nodules are also present. Bivalves are the dominating fossil group, although ammonoids and fish remains are also present.

Unit M.-This consists of medium dark grey silty shale with interbedded sandstone laminae and beds. Very fine-grained sandstone beds grade upwards into shale. Such beds have sharp bases and some of the beds show transitions from parallel lamination in their lower parts to ripples in their upper parts. Carbonate pellets are common in the coarser-grained parts of the beds. A few phosphate nodules occur throughout the unit. Bioturbation is abundant and concentrated in the shales. Abundant bivalve fragments. ammonoids and wood remains as well as some gastropods, ostracodes and bryozoans occur throughout the unit.

Unit N.-This is a $5.55 \mathrm{~m}$ thick, very fine-grained, calcite cemented, bioturbated sandstone. The basal $10 \mathrm{~cm}$ comprises a limestone bed with a gradational upper transition to silty shale. The top of the unit is marked by a fine-grained rippled $15 \mathrm{~cm}$ thick sandstone bed. Poorly preserved bivalves and ammonoids are present. The unit contains abundant phosphorite nodules, often ellipsoidal with the long axis parallel to the bedding.

Unit O.-This consists of very dark grey laminated shale, with abundant small phosphorite nodules. The basal $1.1 \mathrm{~m}$ consists of grey shale overlain by a $45 \mathrm{~cm}$ thick massive bioturbated fine-grained sandstone bed. Bivalves and ammonoids are abundant and in the lower part of the unit there are also some wood fragments and fish 

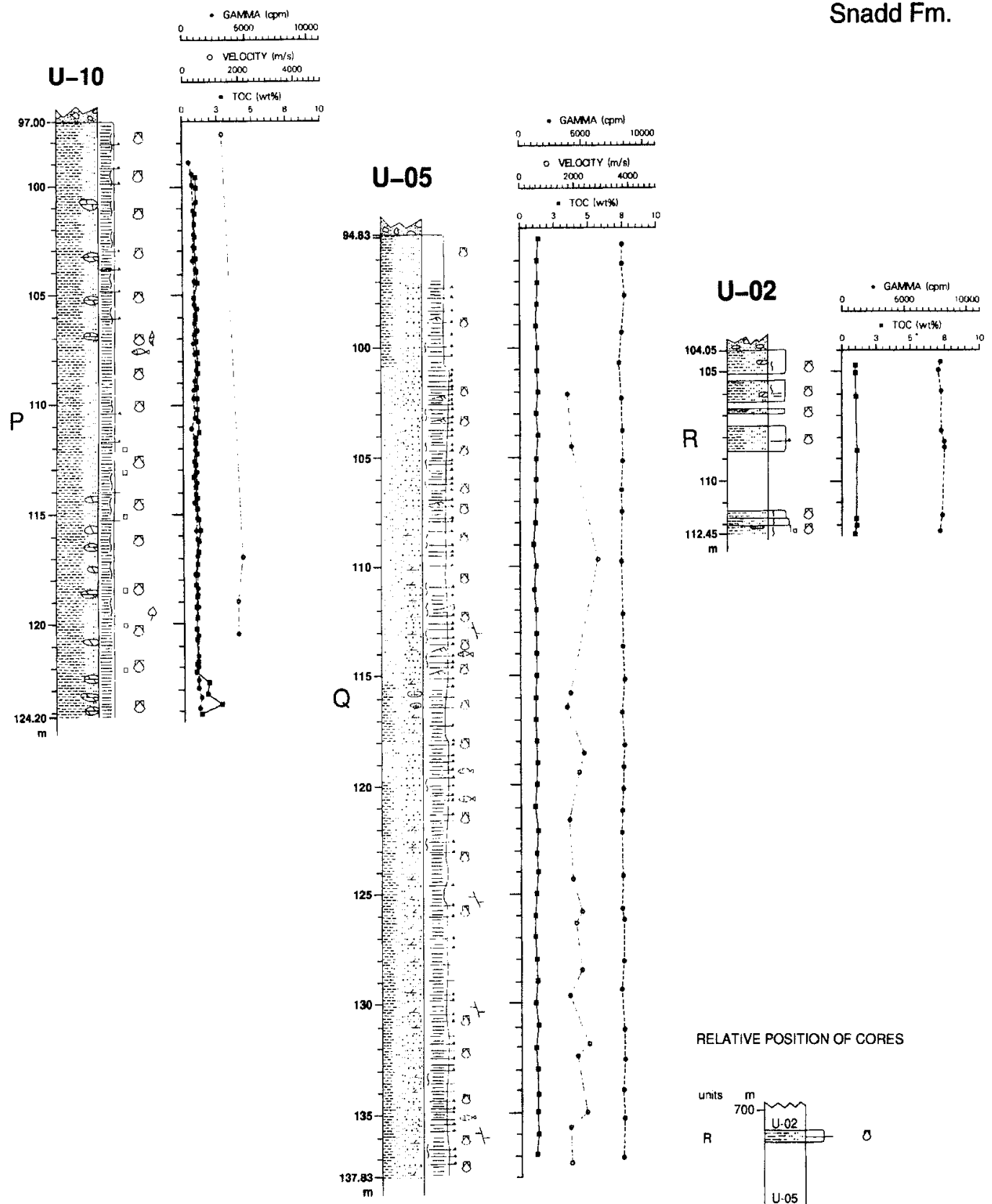

RELATIVE POSITION OF CORES

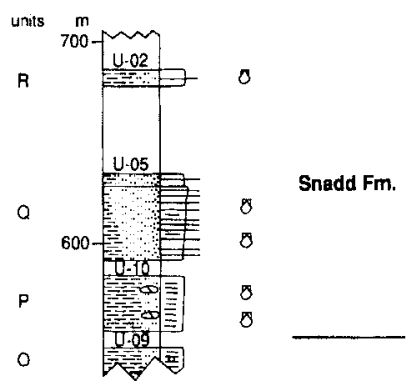

Fig. 12. The Snadd Formation (legend with Fig. 6). 


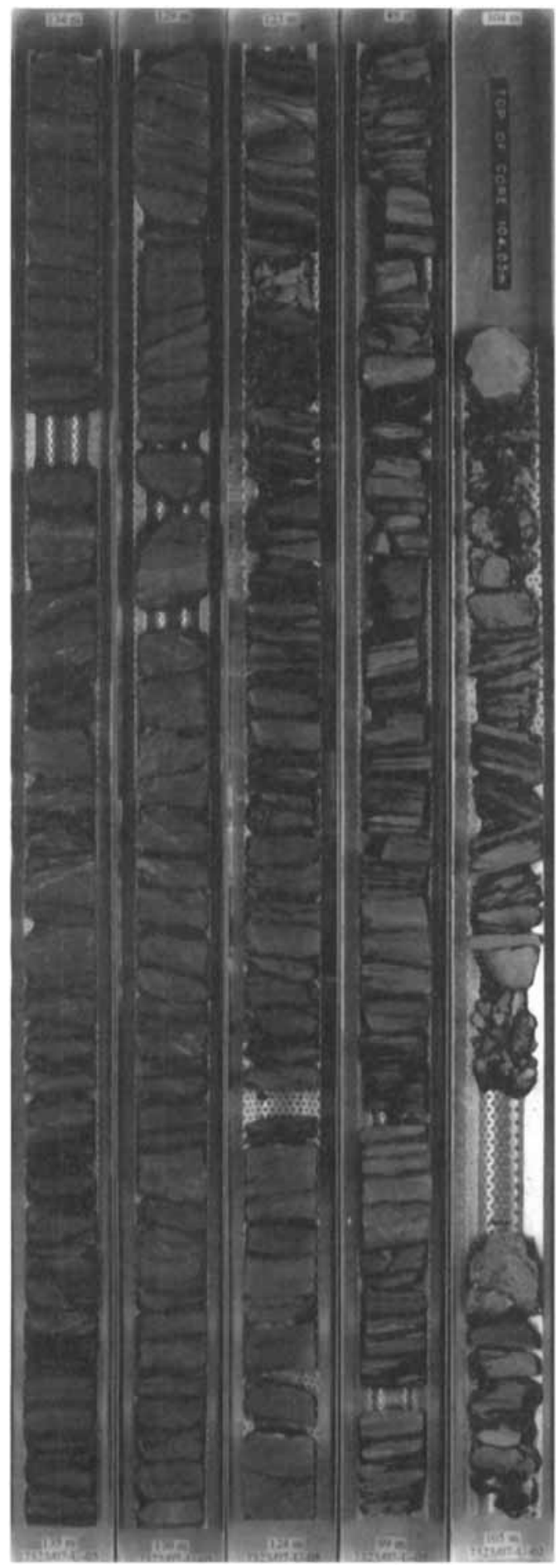

Fig. 13. Core photos from the Snadd Formation. Each core is $5 \mathrm{~cm}$ wide. remains. Some of these nodules also contain euhedral baryte crystals.

Snadd Formation; cores 7323/07-U-10, U-05, U02

The Snadd Formation comprises the three cores, 7323/07-U-10, U-0S and U-02 representing the youngest sampled sediment at the Svalis Dome. The dominantly grey siltstones and sandstones (Figs. 12,13) are similar to lithologies described and defined by Worsley et al. (1988) in the Hammerfest Basin as the Snadd Formation. TOC values are fairly high for all cores (approximately $1 \%$ ), but significantly lower than in the underlying Steinkobbe Formation. Gamma radiation measurements (cores U-05 and U-02) show a smooth pattern. (Figs. 3, 12).

Unit P.-This consists of grey to dark grey laminated silty claystone with a faint coarsening upward trend. The upper part contains abundant sharply based siltstone laminae grading into overlying claystone. Small siderite nodules, a few centimetres in diameter, occur sporadically, while micronodules less than one $\mathrm{mm}$ in size are abundant throughout the core and represent siderite replacements of faecal pellets. Sparse bioturbation is seen throughout the unit but is more abundant in the upper part. The core is very rich in bivalves and both a small and a larger thin-shelled form are present. Gastropods, leaf and wood fragments and fish remains are also present. The lower $2 \mathrm{~m}$ show high TOC values (ca. $2 \%$ ).

Unit Q.-This consists of bluish grey clayey siltstone. Brownish, thin siltstone beds grade upwards into claystone, and sandstone laminae from a few millimetres to $1.5 \mathrm{~cm}$ thick become increasingly common upwards in the core. Some of these beds show low angle cross-lamination. Bivalve fragments and sporadic fish remains occur throughout the core.

The bedding is highly disturbed, commonly oblique, and in some places almost vertical. The true stratigraphical thickness is thus not known. Microfaults, often orientated subparallel to the lamination, are abundant.

Unit R.-This consists of grey to medium dark grey sandy to clayey siltstone. Abundant bioturbation disrupt the original bedding. Some phosphorite and sideritic nodules occur at several 
levels. Bivalve fragments are fairly common. Only part of the drilled interval could be cored because of technical problems; however, the recovered core pieces are quite similar to each other.

\section{Depositional processes}

The Svalis Dome is located in the south-western part of the Maud Basin which developed from the late Palaeozoic through the Lower and Middle Triassic (cf. Gabrielsen et al. 1990). To the south and south-west the basin is bounded by the subaerially exposed Loppa High (e.g. Van Veen et al. 1993), to the west by a poorly defined late Early Triassic to Anisian high connecting the Loppa High to the Stappen High. To the east of the Maud Basin the Mercurius High continues northwards along the westernmost part of the Sentralbanken High, and is separated from the Maud Basin by the Hoop Fault Complex. A narrow, mainly north-south orientated marine basin, the West Barents Sea Bight, includes the Maud Basin and seems to connect the Svalbard Basins with the western Bjarmeland Platform/eastern Loppa High Triassic basin. The proximity of the Svalis Dome cores to the land area of the Loppa High and its continuation towards north implies that facies evolution was largely controlled by sediment influx from this area until the end of the Anisian. In the Ladinian, large-scale subsidence of the western Barents Sea, including drowning of the Loppa High, took place contemporaneously with the large-scale westward coastal progradation from the mainland of Norway (Van Veen et al. 1993) and from poorly defined land area towards north-east (cf. M. B. E. Mørk 1999).

The sediment of the Svalis Dome cores can be grouped in four lithofacies types (Figs. 3, 4) successively representing decreasing energy levels in marine basinal facies below storm wave base. The lithofacies types are: 1) sandstones, dominated by thin fining upwards beds; 2) laminated siltstones with graded sandstone lamina: 3) laminated silt- and claystones; 4) dark organic-rich phosphoritic mudstones. The facies range from gravity deposited sandstones representing submarine fans along the basin margin to black shales representing distal or anoxic basin. The repeated intermixing of the lithofacies types indicates that only minor basinal changes took place in the Svalis Dome area during the Early and Middle Triassic. The abundance of terrestrially derived plant material in the coarser facies seems to reflect the advance and retreat of palaeo-shoreline towards the Loppa High. High amounts of terrestrially derived material occur in the most proximal facies while more amorphous material dominates the distal marine setting (see figure 2 [palynofacies diagram] in Vigran et al. 1998).

Lithofacies I, "Sandstones, dominated by thin fining upwards beds".- This occurs only in the lower cored part of the Klappmyss Formation. This lithofacies comprises stacked fining upward beds, and represents deposition during the highest energy level recorded near the Svalis Dome. Beds thicker than $50 \mathrm{~cm}$ that fine slightly upwards occur in the lower part of the unit, although most of the beds are only a few centimetres thick and form stacks. Occasional graded laminae (as described below) are also present. The thicker sandstone beds, often with sharp bases which may be erosive or show flute casts, show an upward change from massive, to laminated, to crossbedded or rippled laminated character, grading finally into laminated siltstones rich in macrospores and other terrestrially derived plant remains. Thinner beds typically lack the lower laminated unit and the cross-laminated unit.

Climbing ripples, convolute bedding and loading as well as lack of bioturbation in the sandstones indicate short pulses of rapidly deposited sand. The sharp and erosive base of many of the beds reflects high-energy deposition. Benthic organisms are only recorded in the interbedded fines and indicate that the fines represents slow sedimentation from suspension allowing establishment of benthic communities. The fining upwards trend of each beds and hierarchy of the sedimentary structure reflects deposition during waning energy.

Intervals with thin beds that fine up and also have a succession of sedimentary structures showing decreasing energy level upwards are often attributed to turbidity currents (Walker 1984a, 1984b). In this lithofacies siltstone and claystone are very subordinate, and the distinct suite of structures forming the different parts of well-developed turbidites have not been observed. Postma et al. (1988) reported well-developed turbidites developed entirely in sandstones, and Nemec \& Steel (1984) described turbidity currents 
triggered by subaqueous debris flows. Storm processes are widely recognized for transporting sand in moderately deep shelf environment (cf. Johnson \& Baldwin 1986). Walker (1984a) describes incremental sand movements by stormgenerated geostrophic flow which may transport sand from shallow areas into the basin.

The graded beds from lithofacies 1 may represent either storm deposits or sediment redistributed by turbidity currents (cf. Walker 1984a, 1984b). Both processes create fining upward beds that are often terminated with rippled tops overlain by pelagic fine-grained sediment. The overall fining upward grain-size trend reflects a gradual reduction of sand supply and may be due to a transgressive development with gradual submergence of the provenance area, or alternatively the sandstone can represent a wedge formed during the low sea level terminating the previous regressive systems tracts.

During the late Smithian the relief may still have been steep enough for gravity induced sediment transport to occur and/or the relief may have been repeatedly increased due to tectonic movements along fault zones (Hoop Fault Complex). It should be noted that tectonic activity started at this time in the Nordkapp Basin (Nilsen et al. 1995). The wedge-shaped geometries seen on seismic data from the area (e.g. Bugge \& Fanavoll 1995) and small synsedimentary faults in the overlying facies are indications of syn-tectonic deposits. The sediment may have been eroded from foot-wall blocks and deposited in the halfgrabens by turbidite currents-dominated submarine fans.

The association of lithofacies 1 and 2 (see below), combined with thinning of the sedimentary succession basinward (cf. Fig. 2), make a gravity flow depositional mechanism the most likely interpretation, whether the gravity flows have been triggered by tectonics or by storms.

Lithofacies 2, "Laminated siltstones with graded sandstone laminae".-This forms a significant part of the lithology of the Klappmyss and Snadd formations, although very fine-grained sandstone beds, generally less than $5 \mathrm{~cm}$ thick, are also common. The beds have sharp bases and a gradational transition to overlying silty shales. The thicker beds typically show an upward change in structures from massive through rippled to laminated units and finally into silty shales. Often only thin laminae of sand grains are present.
Locally such beds may show ripple lamination. Yellowish brown dolomite or reddish brown siderite concretions are common in the lithofacies and may represent condensed beds. Rapid sedimentation of adjacent beds is indicated by soft sediment deformation structures. Bioturbation is mostly sparse and typically confined to the interbedded fines, and displays a low-diversity ichnofabric. No extensive benthic colonization took place on the sea bottom. This lithofacies shows a coarsening upward grain size trend resulting from a gradual increase in the thickness and frequency of sandstone beds.

The formation of such laminae may be related to storm mechanisms in a distal basinal position. In more proximal parts of the basin graded sandstone beds were deposited while only minor amounts of sediment were transported into the distal parts of the basin. It should be noted that such graded laminae are not associated with bioturbation. Like the lithofacies type described above both a storm and turbidity current mechanism may be responsible for the deposition of the graded laminae. They clearly represent a starved situation with little sand available, and may represent the distal development of turbidites similar to the graded beds of the sandstone facies. The facies was deposited in a low-energy, well-oxygenated marine basin with occasional deposition of distal turbidite beds. It represents a more distal marine position than the sandstone facies discussed above.

Lithofacies 3, "Laminated silt- and claystones".--This is differentiated from the laminated siltstones mainly on the basis of its higher clay content and lack of graded sandstone lamina. The lithofacies constitutes the cored part of the Havert Formation as well as minor intervals of the other formations. Calcite, siderite and dolomite concretions are present in this lithofacies. The lithofacies is characterized by pelagic sediments and fossils (ammonoids and thin-shelled bivalves). The lithofacies clearly represents more distal deposits than the other facies described above and is interpreted to represent open wellventilated shelf environments.

Lithofacies 4, "Dark organic-rich phosphatic mudstones".-This dominates the Steinkobbe Formation. The lithofacies consists mainly of dark to very dark unbioturbated "paper" shales that are more or less silty. Sandstone beds and laminae are only occasionally present. Phosphor- 
ite occurs both as small nodules and as thin beds. The organic content of this lithofacies is high (ca $1-8 \%$ TOC) and the lithofacies represents an excellent source rock for hydrocarbons. Pyrite occurs as single crystals/aggregates occurring both as framboids and as thin laminae, and phosphorite nodules (discussed below) are quite abundant. Pelagic fossils such as ammonoids, thin-shelled bivalves and fish remains occur in large quantities throughout the lithofacies, and bioturbation is absent or rare.

The presence of planktonic fossils such as ammonoids. thin-shelled bivalves or fishes, while no bioturbation occur in the sediment indicate an oxic sea-water overlying oxygen-poor sea floor waters. The high TOC, pyrite and phosphorite content of the Steinkobbe Formation indicates concentration of organic matter at the sea bottom due to low sedimentation rates and anoxic/dysoxic sea floor conditions. The sediment represents a more distal and restricted setting than the other lithofacies. The deposition may have taken place within a large bight, possibly with a stratified water column.

Phosphorite.-Phosphorite nodules are very common in lithofacies 4 of the Steinkobbe Formation, and their occurrence is similar to that observed in the Botneheia and Bravaisberget formations of Svalbard (Mørk, Knarud et al. 1982; Mørk, Dallmann et al. in press).

Two types of phosphorites are present. The most common type is light yellowish brown elongated nodules/lenses of collophane cement. They typically are massive or laminated and are orientated concordantly with the bedding in the surrounding sediments. They rarely exceed $1 \mathrm{~cm}$ in thickness. The nodules are mostly flattened and elongated and do not show internal structures. The nodules have a micritic brown collophane matrix. and some of the nodules show zoning with a core of microcrystalline calcite surrounded by a phosphorite rim. XRD analyses show that the phosphorite mineral is a carbonate-fluor-apatite (francolite) with an average composition as given by five microprobe analyses:

$$
\begin{gathered}
\left(\mathrm{Ca}_{4.84} \mathrm{Sr}_{.01} \mathrm{Fe}_{.09} \mathrm{Mg}_{.03} \mathrm{Na}_{.04}\right) \\
\left.\left[\left(\mathrm{PO}_{44}\right)_{2.75}\left(\mathrm{SO}_{4}\right)_{.03}\left(\mathrm{CO}_{3}\right)_{.22}\right)\right]\left(\mathrm{F}_{.78} \mathrm{Cl}_{.01}(\mathrm{OH})_{.37}\right) .
\end{gathered}
$$

The second type of phosphorite consists of black to dark brown spherical to ellipsoidal shaped nodules/pebbles a few centimetres in diameter. They have a fine to medium grained texture consisting of pelloidal shaped phosphorite grains cemented by a fringe of fibrous pore lining phosphorite cement. Electron microprobe analyses show similar composition as for the yellowish brown phosphorite. This type of phosphorite also occurs in lithofacies 2 and 3.

Studies on the shelf off East Australia (O'Brien et al. 1990; Heggie et al. 1990) show that active phosphatization has taken place since the late Tertiary in moderate deep shelf environments $(300-500 \mathrm{~m})$ in the uppermost part of an anoxic sediment column, and $10-18 \mathrm{~cm}$ below the sediment-water interface. The process includes the reductive dissolution of iron oxyhydroxides and their reprecipitation at the oxic/anoxic boundary. Phosphate released from organic matter and fluoride from sea-water are, via several stages, made available for the phosphatization. These processes take place while oxic conditions occur in the overlying seawater. This direct precipitation of phosphate and associated glauconitization is favoured by high organic carbon input, low current velocities and a high sea level. This mechanism partly conflicts with a replacement mechanism where primary carbonate minerals are replaced by phosphate, as suggested by Kennedy \& Garrison (1975) for the Cretaceous chalks. Lewy (1990), in a study of Cretaceous pebbly phosphates from Israel, attributes the phosphatization mainly to the activity of endobenthic micro-organisms. He questions both direct precipitation and phosphate replacement of carbonates, and suggests that in many deposits phosphate precipitating microorganisms have penetrated and mineralized lithified carbonates.

The high organic content and the lack of bioturbation in the phosphate-containing beds at the Svalis Dome may indicate similar sea bottom conditions as those leading to phosphatization off Australia. Anoxic sea bottom conditions are also indicated by the abundant pyrite content in these beds, while in other parts of the succession both siderite and iron-rich dolomite nodules dominate. Oxic conditions in the water column are documented by the abundant pelagic fossils and the high organic productivity.

In the Middle Triassic sediments of Svalbard, phosphatization of fossil shells is common. Primary aragonitic forms, like ammonoids, are mostly subjected to such phosphatization (Weitschat 1986; Weitschat \& Bandel 1991) and our own observations clearly indicate that a replacement mechanism has been active, as has 
been suggested by Mørk, Knarud et al. (1982), especially in fossil shells and within trace fossil tunnel fillings. The compactionally flattened nature of the nodules at the Svalis Dome may also indicate phosphatization early in the diagenetic process.

Type one phosphorite is confined to laminated dark grey to black laminated shales. They probably were mainly formed by phosphorite replacement of calcium carbonate minerals close to the sea floor. Type two phosphorite probably formed by phosphoritization of calcium carbonate faecal pellets followed by precipitation of a pore lining fibrous phosphorite cement. Both types of phosphorites are common in the Botneheia Formation of eastern Svalbard where phosphate often replaces large burrows.

Sedimentation rates. - Estimates of sedimentation rates at stage level are shown in Fig. 14. The apparently low sedimentation rates for the Havert Formation may reflect imprecise estimates for the duration of a depositional break in the earliest Triassic; if this break is assumed to span the Otoceras ammonoid Zone, the sedimentation rate estimate will increase by about $30 \%$.

Highest sedimentation rates are indicated in the Klappmyss Formation (lithofacies 1). The lower part of this unit consists of rapidly deposited massflow sandstones, while the remaining cored part of the formation displays abundant distal turbidites or storm-deposited beds, both indicating active sedimentation processes in a setting with abundant available sediment derived from shallower shelf areas.

The slowest sedimentation rates are estimated for the organic-rich lithofacies 4 of the Steinkobbe Formation of Spathian and Anisian age. Sedimentation took place in restricted environments with very low sediment influx from surrounding areas, resulting in deposition mostly of pelagic clay.

A clear change in sedimentary regime is seen when passing from the dark claystones of the Steinkobbe Formation to the grey shales of the Snadd Formation. The thickness of the Snadd Formation is not known as the top has not been drilled. Although as a result of this only minimum estimates for the sedimentation can be given, they do indicate greater sedimentation rates compared to the Steinkobbe Formation.

\section{Local sedimentation and sequence development}

Tectonic activity along the Hoop Fault Complex took place during the Early and Middle Triassic (Bugge \& Fanavoll 1995). The consequent thickening of the sedimentary units towards this fault can be observed in Fig. 2. No movements in the interpreted underlying salts are interpreted for this time period (figure 8 in Bugge \& Fanavoll 1995). However, faults at the very end of the Triassic, or later, may have contributed to salt movements. Movement along the Hoop Fault Complex may have created a significant topography in the Early and Middle Triassic, and repeated reactivation along this fault complex may have controlled sand production and gravity flow sedimentation.

The stacked lithofacies patterns of the Svalis Dome area form a series of transgressive-regressive (T-R) sequences, and the relationship between these sequences and the seismic stratigraphy is presented by Vigran et al. (1998).

\begin{tabular}{|l|c|}
\hline Formation & $\begin{array}{c}\text { Stage/ } \\
\text { Substage }\end{array}$ \\
\hline Snadd & Ladinia $\mathrm{L}$ \\
\hline Steinkobbe & Anisian \\
\cline { 2 - 3 } & Spathian \\
\cline { 2 - 3 } Klappmyss & Smithian \\
\hline Havert & Griesb.-Diener \\
\hline
\end{tabular}

\begin{tabular}{|l|c|c|}
\hline$M^{*}$ & $\begin{array}{c}\text { Metres of } \\
\text { deposition }\end{array}$ & $\begin{array}{c}\text { Sedimentation } \\
\text { rate } \mathrm{m} / \mathrm{Ma}\end{array}$ \\
\hline 227 & $?$ & \\
231 & 120 & $40+$ \\
234 & 190 & 24 \\
242 & 70 & $70-\quad 29-$ \\
\hline 243 & 185 & \multicolumn{2}{|c|}{$93+$} \\
\hline 245 & 115 & $38+\quad 57^{\star \star}$ \\
\hline
\end{tabular}

- From Gradstein \& Ogg 1996

** Assuming that no sedimentation took place in the two lower zones

\section{Sedimenation rate} $\mathrm{m} / \mathrm{Ma}$

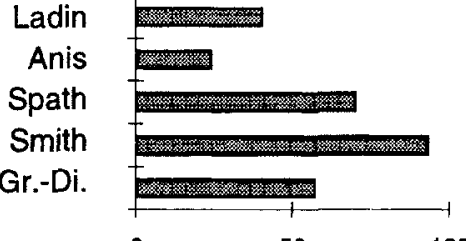

0 100

Fig. 14. Sedimentation rates during the Early and Middle Triassic on the Svalis Dome. 
No proximal sediments occur in the Svalis Dome area, making shoreline trajectory mapping as used by Helland-Hansen \& Gjelberg (1994) to map transgressions and regressions impossible; assignment of $T-R$ sequences is thus only based on sedimentary responses to deepening and shallowing of the depositional basin. The cored intervals through these six sequences (Fig. 3) contain four sequence boundaries, but only two maximum flooding surfaces. Without full core coverage (or continuous logs) sequence interpretation will be speculative, but the fragmentary core data suggest that the transgressive parts of the sequences are fairly extensively sampled. One explanation may be that in this distal location, most of the deposition is the result of sediment transportation into the basin during the latest lowstand. transgressive and/or highstand phases. Regressively induced progradation, which at the same time resulted in extensive depositional outbuilding on Spitsbergen, did not reach the distal environs of the Svalis Dome, at least not before the Ladinian (sequence 6). A well-developed transgressive systems tract is seen in the $70 \mathrm{~m}$ thick succession of cores U-08 and U-06 (sequence 2 of Fig. 3), where decreasing energy levels are indicated by the lithofacies succession.

Triassic transgressive-regressive cycles have been recognized throughout the western Arctic by Mørk, Embry et al. (1989) based on data from Svalbard and the Sverdrup Basin. The sequence boundaries reported by Van Veen et al. (1993) and Rasmussen et al. (1993) correspond to those reported by us (Fig. 3; Vigran et al. 1998), although the order of the boundaries is reported differently. Embry (1997) has subdivided the Triassic succession with 12 sequence boundaries of second and third order (order concept of Embry 1993, 1995) which he claims are global in extent. Five of the Lower and Middle Triassic boundaries of the Svalis Dome can also be correlated to Svalbard, the Sverdrup Basin and East Siberia (Mørk 1994, 1997; Embry 1997; Egorov \& Mørk in press). The intra-Anisian sequence boundary interpreted between core U-04 and core U-01 may correspond to a reported sequence boundary further east in the Barents Sea (Rasmussen et al. 1993), but this boundary has not yet been recognized in Svalbard. In East Siberia several lower order sequence boundaries also occur within the Anisian succession (Egorov \& Mørk in press).

At present we cannot demonstrate the correlation of lower order sequences between remote areas; a local tectonic mechanism such as movements along the Hoop Fault Complex (Bugge \& Fanavoll 1995) may be responsible for local relative sea level fluctuations. This interpretation is supported to some extent by the comprehensive organic geochemical study from the Svalis Dome cores by Isaksen \& Bohacs (1995), from which they conclude that sequence stratigraphy (Exxon second order sequences) control deposition of the organic matter. Their study is mainly based on the five cores from the Steinkobbe Formation. They interpret the presence of five sequence boundaries, although only two of these coincide with sequence boundaries recognized in our study. They also identify 29 flooding surfaces, i.e. they interpret the presence of a flooding surface on most changes in lithology, a high content of organic material or variations in gamma radiation. They do not, however, include the undrilled intervals between the cores in their interpretations.

Our study shows that the Svalis Dome display the same basic sequence pattern for higher order sequences as reported throughout the Arctic (Mørk 1994: Egorov \& Mørk in press) or possibly globally (Embry 1997). The lower order sequence pattern in the western Barents Sea may reflect the local tectonic and palaeogeographic development. The higher order sequences have a great potential in helping to delineate the factors controlling regional source and reservoir rock developments.

\section{Conclusions}

- The Lower and Middle Triassic succession is more than $700 \mathrm{~m}$ thick; $315 \mathrm{~m}$ of this succession have been cored in 11 coreholes, and the sediments have been dated by both macrofossils and palynomorphs.

- The cores can be assigned to the Havert, Klappmyss and Snadd formations as defined in the Hammerfest Basin. Dark organic-rich shales (Spathian and Anisian) form the Steinkobbe Formation that resembles penecontemporaneous lithofacies from Svalbard.

- The succession forms a minimum of six transgressive-regressive sequences.

- The Steinkobbe Formation (formally defined herein) represents rich hydrocarbon source rocks and was deposited in a large bight of the palaeo-Arctic Ocean. Anoxic conditions favouring the preservation of organic material devel- 
oped already in the Spathian in the Svalis Dome area, whereas such conditions evolved later during the Anisian and Ladinian at Svalbard, and continued even further into the Carnian in the Sverdrup Basin (Embry 1991).

Acknowledgements. - Illustrations were prepared by the technical staff at IKU/SINTEF Petroleum Research. Data were collected during the IKU Barents Sea Mapping Program, which was supported by many oil companies. Paul Grogan and David Worsley are thanked for suggestions to improve an early version of the manuscript

\section{Appendix}

\section{Definition of the Steinkobbe Formation}

Name.-The formation is named after the common Norwegian seal Phoca vitulinan; the species is included in the general term "kobbe" which is the basis of the name of the partly equivalent Kobbe Formation in the Hammerfest Basin.

Well type section.-The Steinkobbe Formation (Figs. 10, 11) occurs in the Svalis Dome area, and its base is defined in corehole 7323/07-U-03 $\left(73^{\circ} 16^{\prime} 33.702 \mathrm{~N}, 23^{\circ} 03^{\prime} 26.430 \mathrm{E}\right)$. Parts of the formation are also drilled higher in the succession, along the same seismic line IKU D86-144 (Figs. $1,2)$ in coreholes $7323 / 07-U-04\left(73^{\circ} 16^{\prime} 37.701 \mathrm{~N}\right.$, $\left.23^{\circ} 02^{\prime} 59.887 \mathrm{E}\right), 7323 / 07-\mathrm{U}-01\left(73^{\circ} 16^{\prime} 42.638 \mathrm{~N}\right.$, $\left.23^{\circ} 02^{\prime} 32.204 \mathrm{E}\right), 7323 / 07-\mathrm{U}-07\left(73^{\circ} 16^{\prime} 47.630 \mathrm{~N}\right.$, $\left.23^{\circ} 02^{\prime} 03.494 \mathrm{E}\right)$ and $7323 / 07-\mathrm{U}-09$ (73 $16^{\prime}$ $\left.51.007 \mathrm{~N}, 23^{\circ} 01^{\prime} 43.137 \mathrm{E}\right)$. The overlying corehole $7323 / 07-\mathrm{U}-10$ is regarded as belonging to the Snadd Formation.

Thickness.-The unit is approximately $250 \mathrm{~m}$ thick in the type area.

Lithology.-The unit consists of dark, phosphatic, organic-rich "paper" shale/mudstone (TOC between 1.5 and $9 \%$ ), with minor siltstones. The lower part the core is thinly (papery) laminated and no bioturbation is seen. Higher in the formation faint bioturbation partly destroys the lamination. Phosphorite nodules are abundant and occur as globular or flattened nodules a few centimetres in diameter. At some levels phosphoritic beds, or flattened nodules, are larger than the core diameter. Thin beds of limestone and siltstone beds with calcite, dolomite or siderite cements, also occur. Pyrite is abundant throughout most of the core.

In the middle part of the formation (cores U-01 and U-07) the lithology is dominated by siltstone and some sandstone laminae also occur. These may show ripples and fining upward textures.

Flattened bivalves and ammonoids are very abundant, but sometimes they are only preserved as imprints. Fish fragments, mostly scales, and some reptile fragments are also present. All these fossils represent pelagic fossil groups.

Basal stratotype.-The base is defined at the abrupt transition from siltstone to dark organicrich shale (between units $F$ and $G$ ) at a depth of $107.05 \mathrm{~m}$ in core $7323 / 07-\mathrm{U}-03$. At this level there is also a sharp increase in gamma radiation and the content of organic carbon increases to $3-4 \%$. The Steinkobbe Formation rests conformably on the Klappmyss Formation without any erosional structures or lag deposits.

Age.-The basal beds are dated as early Spathian by palynomorphs, and the entire formation is of Spathian and Anisian age based on both ammonoids and palynomorphs (Vigran et al. 1998), while the overlying Snadd Formation contains Ladinian palynomorphs.

Depositional environments.-The Steinkobbe Formation was deposited in a deep shelf environment with restricted water circulation. The sea bottom was mostly anoxic, interrupted by shorter periods with oxygenation as evidenced by the sporadic bioturbation.

Correlations and hierarchic position.-The unit is time equivalent to the upper part of the Klappmyss Formation and to most of the Kobbe Formation of the Hammerfest Basin (Worsley et al. 1988). The Steinkobbe Formation, however, has much higher organic content than these units. In the east in the Nordkapp Basin equivalent beds consist of coastal sandstones (Bugge, Elvebakk et al. in press). On Bjørnøya only the phosphate nodules of the Verdande Bed of the Urd Formation (Mørk, Vigran \& Hochuli 1990) may be correlated to the Steinkobbe Formation. The over- and underlying hiati bounding the Verdande Bed may be time equivalent to the remainder of the Steinkobbe Formation, which may also have been originally deposited in the Bjørnøya area prior to subsequent lowstand erosion and winnow- 
ing. On Svalbard the upper part of the Barents $\varnothing y a$ Formation (sensu Mørk, Knarud et al. 1982) are similar to the Steinkobbe Formation (i.e. the Vendomdalen Member of the Vikingh $\varnothing$ gda Formation and the Botneheia Formation of Mørk, Dallmann et al. (in press) and Mørk, Elvebakk et al. (1999). Both lithological developments and organic and fossil contents are directly comparable.

\section{References}

Bugge, T. \& Fanavoll, S. 1995: The Svalis Dome, Barents Sea a geological playground for shallow stratigraphic drilling. First Break 13(6), 237-251.

Bugge, T., Elvebakk, G., Fanavoll, S., Mangerud, G., Smelror, M., Weiss, H. M. \& Kristensen, S. E. in press: The Mesozoic succession of the Nordkapp Basin, Barents Sea. Pet. Geosci.

Bugge, T., Mangerud, G., Elvebakk, G., Mørk, A., Nilsson, I., Fanavoll, S. \& Vigran, J. O. 1995: The Upper Paleozoic succession on the Finnmark Platform, Barents Sea. Norsk Geologisk Tidsskrift 75, 3-30.

Egorov A. Y. \& Mørk, A. in press: The East Siberian and Svalbard Triassic successions and their sequence stratigraphical relationships. In Lerche, I. \& Bachmann, G. B. (eds.): Proceedings of the Epicontinental Triassic International Symposium, Halle/Saale 1998. Springer.

Embry, A. F. 1991: Mesozoic history of the Arctic Islands. In Trettin, H. P. (ed.): Arctic islands. Geology of the Innuitian Orogen and Arctic Platform of Canada and Greenland. Geological Survey of Canada. Geology of Canada 3, $370-433$.

Embry, A. F. 1993: Transgressive-regressive (T-R) sequence analysis of the Jurassic succession of the Sverdrup Basin, Canadian Arctic Archipelago. Can. J. Earth Sci. 30, 301-320.

Embry, A. F. 1995: Sequence boundaries and sequence hierarchies: problems and proposals. In Steel et al. (eds.): Sequence stratigraphy on the northwest European Margin. Elsevier, Amsterdam. Norwegian Petroleum Society (NPF) Special Publication 5, 1-11.

Embry, A. F. 1997: Global sequence boundaries of the Triassic and their identification in the western Canada sedimentary basin. Canadian Petroleum Geology Bulletin 45(4), 415-433.

Faleide, J. I., Gudlaugsson, S. T. \& Jacquart, G. 1984: Evolution of the western Barents Sea. Marine and Petroleum Geology 1, $123-150$.

Gabrielsen, R. H., Færseth, R. B., Jensen, L. N., Kalheim, J. E. \& Riis, F. 1990: Structural elements of the Norwegian continental shelf. Part I: The Barents Sea region. Norwegian Petroleum Directorate Bulletin 6, $33 \mathrm{pp}$.

Gradstein, F. \& Ogg, J.,1996: Geologic timescale. Episodes $19(1-2), 3-5$.

Gramberg, I. S. (ed.) 1988: Barencevskaja šel'fovaja plita (Barents Shelf Plate). VNIIOkeangeologija Trudy, Tom 196, 263 pp. (In Russian.)

Heggie, D. T., Skyring, G. W., O'Brien, G. W., Reimers, C., Herczeg, A., Moriarty, D. J. W., Burnett, W. C. \& Milnes, A. R. 1990: Organic carbon cycling and modern phosphorite formation on the East Australian continental margin: an overview. In Notholt, A. J. G. \& Jarvis, I. (eds.): Phosphorite Research and Development. Geological Society Special Publication 52, 87-117.

Helland-Hansen, W. \& Gjelberg, J. G. 1994: Conceptual basis and variability in sequence stratigraphy: a different perspective. Sedimentary Geology 92, 31-52.

Hulke, I. W. 1873: Memorandum on some fish vertebrate remains collected by the Swedish Expedition to Spitzbergen in 1864 and 1868. Bih. Svensk. Vetenskakad. Handl. 1(9), $1-11$.

Isaksen, G. H. \& Bohacs, K. M. 1995: Geological controls of source rock geochemistry through relative sea level; Triassic, Barents Sea. In Katz, B. (ed.): Petroleum Source Rocks. Pp. 25-50. Berlin: Springer Verlag.

Jacobsen, V. W. \& Van Veen, P. 1984: The Triassic offshore Norway north of $62^{\circ} \mathrm{N}$. In: A. M. Spencer et al. (eds.): Petroleum geology of the North European Margin. Pp. 317-328. London: Norwegian Petroleum Society/Graham \& Trotman.

Johansen, S. E., Ostisty, B. K., Birkeland, Ø., Fedorovsky, Y. F., Martirosjan, V. N., Bruun Christensen, O., Cheredeev, S. I., Ignatenko, E. A. \& Margulis, L. S. 1993: Hydrocarbon potential in the Barents Sea region: play distribution and potential. In Vorren, T. O. et al. (eds.): Arctic geology and petroleum potential. Norwegian Petroleum Society (NPF) Special Publication 2, 273-320.

Johnson, H. D. \& Baldwin, C. T. 1986: Shallow siliciclastic seas. In Reading, H. G. (ed.): Sedimentary environments and facies. Pp. 229-282. Oxford: Blackwell.

Kennedy, W. J. \& Garrison, R. E. 1975: Morphology and genesis of nodular chalks and hardgrounds in the Upper Cretaceous of southern England. Sedimentology 22, 311-386.

Kristoffersen, Y. \& Elverhøi, A. 1978: A diapir structure in Bjørnøyarenna. Norsk Polarinstitutt Arrbok 1977, 189-198.

Leith, T. L., Weiss, H. M., Mørk, A., Århus, N., Elvebakk, G., Embry, A. F., Brooks, P. W., Stewart, K. R., Pchelina, T. M., Bro, E. G., Verba, M. L., Danyushevskaya, A., Borisov, A. V 1993: Mesozoic hydrocarbon source-rocks of the Arctic region. In Vorren, T. O. et al. (eds.): Arctic geology and petroleum potential. Norwegian Petroleum Society (NPF) Special Publication 2, 1-25.

Lewy, Z. 1990: Pebbly phosphate and granular phosphorite (Late Cretaceous, southern Isracl) and their bearing on phosphatization processes. In Notholt, A. J. G. \& Jarvis, I. (eds.): Phosphorite research and development. Geological Society Special Publication 52, 169-178.

Mørk, A. 1994: Triassic transgressive-regressive cycles of Svalbard and other Arctic areas: a mirror of stage subdivision. In Guex, G. \& Baud, A. (eds.): Recent developments on Triassic stratigraphy. Mémoires de Géologie (Lausanne) 22, 69-82.

Mørk, A. 1997: Triassic sequences, stages and high order sequence boundaries. Albertiana 19, 9-11.

Mørk, A., Dallmann, W. K., Dypvik, H., Johannessen, E. P., Larssen, G. B., Nagy, J., Nøttvedt, A., Olaussen, S., Pchelina, T. M. \& Worsley, D. in press: Mesozoic lithostratigraphy. In Dallmann, W. K. (ed.): Lithostratigraphic Lexicon of Svalbard. Tromsø, Norway: Norwegian Polar Institute.

Mørk, A., Elvebakk, G., Forsberg, A. W., Hounslow, M. W., Nakrem, H. A., Vigran, J. O. \& Weitschat, W. 1999: The type section of the Vikinghøgda Formation: a new Lower Triassic unit in central and eastern Svalbard. Polar Res. 18(1), 51-82.

Mørk, A., Embry, A. F. \& Weitschat, W. 1989: Triassic transgressive-regressive cycles in the Sverdrup Basin, 
Svalbard and the Barents Shelf. In Collinson, J. D. (ed.): Correlation in hydrocarbon exploration. Pp. 113-130. London: Norwegian Petroleum Society/Graham \& Trotman.

Mørk. A.. Knarud, R. \& Worsley, D. 1982: Depositional and diagenetic environments of the Triassic and Lower Jurassic succession of Svalbard. In Embry, A. F. \& Balkwill, H. R. (eds.): Arctic geology and geophysics. Canadian Society Petroleum Geology Memoir 8, 371-398.

Mørk, A., Vigran, J. O. \& Hochuli, P. A. 1990: Geology and palynology of the Triassic succession of Bjørnøya. Polar Res. 8, 141-163.

Mørk. A., Vigran, J. O., Korchinskaya, M. V., Pchelina, T. M., Fefilova, L. A., Vavilov, M. N. \& Weitschat, W. 1993: Triassic rocks in Svalbard, the Arctic Soviet islands and the Barents Shelf: bearing on their correlations. In Vorren, T. O. et al. (eds.): Arctic geology and petroleum potential. Norwegian Petroleum Society (NPF) Special Publication 2, $457-479$.

Mørk, M. B. E. 1999: Compositional variations and provenance of Triassic sandstones from the Barents Shelf. J. Sedimentary Res. 69(3), 690-710.

Nemec, W. \& Steel, R. J. 1984: Alluvial and coastal conglomerates: their significant features and some comments on gravelly mass-flow deposits. In Koster, E. H. \& Steel, R. (eds.): Sedimentology of gravels and conglomerates. Canadian Socieny Petroleum Geologists Menoir 10, 1-31.

Nilsen, K. T., Vendeville, B. C. \& Johansen, J.-T. 1995: Influence of regional tectonics on halokinesis in the Nordkapp Basin, Barents Sea. In Jackson, M. P. A.. Roberts. D. G. \& Snelson, S. (eds.): Salt tectonics: a global perspective. AAPG Memoir 65, 413-436.

Nilsson, I., Mangerud. G. \& Mørk, A.1996: Permian stratigraphy of the Svalis Dome, southwestern Barents Sea. Norsk Geologisk Tidsskrift 76, 127-146.

O'Brien, G. W., Milnes, A. R., Veeh. H. H.. Heggie, D. T., Riggs. S. R., Cullen, D. J., Marshall, J. F. \& Cook, P. J. 1990: Sedimentation dynamics and redox iron-cycling: controlling factors for the apatite-glauconite association on the East Australian continental margin. In Notholt, A. J. G. \& Jarvis. I. (eds.): Phosphorite Research and Development. Geological Society Special Publication 52, 61-86.

Postma, G., Nemec, W. \& Kleinspehn, K. L. 1988: Large floating clasts in turbidites: a mechanism for their emplacement. Sedimentary Geology 58, 47-61.

Rasmussen, A., Kristensen. S. E., Van Veen, P., Stølan, T. \& Vail, P. R. 1993: Use of sequence stratigraphy to define a semi-stratigraphic play in Anisian sequences, southwestern Barents Sea. In Vorren, T. O. et al. (eds.): Arctic geology and petroleum potential, Nonvegian Petroleum Society $(N P F)$ Special Publication 2, 439-456.
Rise, L. \& Sættem, J. 1994: Shallow stratigraphic wireline coring in bedrock offshore Norway. Scientific Drilling 4 , 243-257

Rønnevik, H. C. 1981: Geology of the Barents Sea. In Illing, L. V. \& Hobson, G. D. (eds.): Petroleum geology of the continental shelf of north-west Europe. Pp. 395-406. London: Heydon \& Son/Inst. Petrol.

Rønnevik, H. C., Beskow, B. \& Jacobsen, H. P. 1982: Structural and stratigraphic evolution of the Barents Sea. In Embry, A. F. \& Balkwill, H. R. (eds.): Arctic geology and geophysics. Canadian Society of Petroleum Geologists Memoir 8, 431-441.

Sundvor, E. 1974: Seismic refraction and reflection measurements in the southern Barents Sea. Marine Geology 16. 255-273.

Van Veen, P. M., Skjold, L. J., Kristensen, S. E.. Rasmussen, A., Gjelberg. J. \& Stølan, T. 1993: Triassic sequence stratigraphy in the Barents Sea. In Vorren, T. O. et al. (eds.): Arctic geology and petroleum potential. Norwegian Petroleum Society (NPF) Special Publication 2, 515-538.

Vigran, J. O., Mangerud, G., Mørk, A.. Bugge. T. \& Weitschat. W. 1998: Biostratigraphy and sequence stratigraphy of the Lower and Middle Triassic deposits from the Svalis Dome, central Barents Sea, Norway. Palynology 22, 89-141.

Walker, R. G. 1984a: Shelf and shallow marine sands. In Walker, R. G. (ed.): Facies Models. Pp. 141-170. Geoscience Canada Reprints Series 1.

Walker, R. G. 1984b: Turbidites and associated coarse clastic deposits. In Walker, R. G. (ed.): Facies Models. Pp.171-188. Geoscience Canada Reprints Series I.

Weitschat, W. 1986: Phosphatisierte Ammonoideen aus der Mittleren Trias von Central-Spitzbergen. Mitt. Geol.-Paläont. lnst. Univ. Hamburg 61, 249-279.

Weitschat. W. \& Bandel, K. 1991: Organic components in phragmocones of Boreal, Triassic ammonoids: implications for ammonoid biology. Palaeontologische Zeitschrift 65(3/4), 269-303.

Wood, R. J., Edrich, S. P. \& Hutchison, I. 1989: Influence of North Atlantic tectonics on the large-scale uplift of the Stappen High and Loppa High, western Barents Shelf. In Tankard, A.J. \& Balkwill, H. R. (eds.): Extensional Tectonics and Stratigraphy of the North Atlantic Margins. AAPG Memoir 46, 559-566.

Worsley, D. \& Edwards. M. B. 1976: The Upper Palaeozoic succession of Bjørnøya. Norsk Polarinstitutt Arbok 1974 , $17-34$.

Worsley, D., Johansen. R., Kristensen, S. E. 1988: The Mesozoic and Cenozoic succession of Tromsøflaket. In Dalland, A., Worsley, D. \& Ofstad, K. (eds.): A lithostratigraphic scheme for the Mesozoic and Cenozoic succession offshore mid- and northern Norway. Nornegian Petroleum Directorate Bulletin 4. 42-65. 